\title{
Индоевропейская прародина и расселение индоевропейцев: подвека исследований и обсуждений
}

\begin{abstract}
Сегодня проблема индоевропейской прародины не потеряла своей актуальности и остается столь же дискуссионной, как и на момент выхода монографии Гамкрелидзе, Иванов 1984. С учетом новых данных, накопившихся за последние три десятилетия (в первую очередь касающихся языковых контактов), мы предлагаем уточненную локализацию района первоначального расселения индоевропейцев: несколько юго-восточнее того ареала, где мы постулировали ее тридцать лет назад. С нашей сегодняшней точки зрения, она располагалась в юго-восточной Анатолии и северной Сирии, непосредственно к северу от Плодородного полумесяца, что позволяет, среди прочего, объяснить древнейшие заимствования из праиндоевропейского языка в семитские, картвельские и восточнокавказские языки. Вместе с тем, хронология данных заимствований не позволяет поддержать гипотезу К. Ренфрю об идентификации праиндоевропейцев с первыми земледельцами на территории Европы. Скорее всего, индоевропейцы появились на европейском континенте поздне́е. С ними было связано распространение других инноваций, а именно: скотоводства и в особенности коневодства.
\end{abstract}

Ключевые слова: индоевропейские языки, семитские языки, кавказские языки, индоевропейская прародина, миграции, скотоводство, земледелие.

Проблема местонахождения индоевропейской прародины (начального центра распространения ранних диалектов праиндоевропейского языка) и ранних этапов расселения их носителей-индоевропейцев давно интересует представителей разных наук - от лингвистов, которые прежде всего устанавливают характер родственных отношений и степень близости друг к другу языков этой семьи, до историков, археологов, антропологов, в последние годы также генетиков, включившихся в обсуждение того, какую картину ранней индоевропейской предыстории можно восстановить. Мы хотим охарактеризовать вопросы, находящиеся в настоящее время в центре внимания ученых.

Современное состояние проблемы, в частности, рассмотрения пространственновременных рамок распространения индоевропейцев по Евразии, определяется прежде всего новыми значительными достижениями в изучении самых ранних письменных свидетельств о древних индоевропейских языках. Отдельные слова этих языков обнаружены в документах XX-XVIII вв. до н. э. на староассирийском диалекте аккадского (семитского) языка из торговых колоний в древней Малой Азии (Анатолии) (Tischler 1995; Dercksen 2007; Иванов 2008; Ivanov 2007а; 2008). В староассирийских текстах (всего их найдено около 23000) отражены имена богов, личные собственные имена и некоторые термины, заимствованные из языков местных жителей, которые относились к двум разным индоевропейским группам - северноанатолийской (к ней принадлежал и представленный позднее большим числом клинописных текстов XVI-XIII вв. до н. э. главный официаль- 
ный язык Хеттской империи - хеттский, или «несийский», как его называли сами хетты по имени города Несы, ассирийского Канища) и южноанатолийской (к ней относится засвидетельствованный несколько более поздними клинописными и иероглифическими документами лувийский язык, на котором во второй половине II тыс. до н. э. говорила основная часть жителей южных и западных областей Анатолии). В последние годы имена двух главных туземных богов обнаружены в документах из археологического слоя II, датируемого XX в. до н. э. (Kryszat 2006; Ivanov 2008).

Один из них назывался именем, которое в староассирийской клинописи передавалось как Ni-pá-as. Выражение i-na ša Ni-pá-as 'во время бога Nipas' указывает на ритуал, занимавший в общей сложности несколько дней. Встречается также приношение $i$-na É Nipá-as 'в храме бога Nipas', отмечается имя его жреца. и упоминается присутствие туземного царя Каниша (главного города этой части Малой Азии) на празднике в этом храме. Имя бога Ni-pá-as обоснованно сравнивают с позднейшим древнехеттским перiš 'небо'. Но наиболее точное соответствие характеру гласных в этой туземной древнеанатолийской форме находится в иероглифическом лувийском ti-pa-sá 'небо' (письменная передача слова, произносившегося как [tipas]), в котором наблюдается и изменение начального согласного ${ }^{*} n->d-/ t$-, сходное с происшедшим в родственном индоевропейском слове в восточно-балтийских языках - литовск. debesis 'облако', латышск. debess 'небо'. К первоначальной общеиндоевропейской форме существительного *nebhos восходит и праславянское название обожествлявшегося неба, откуда русск. небо, небес- $a$, родственное санскритск. nábhas 'облако, туман', древнегреческ. vع́фоऽ 'облако', латинск. nebula 'туман', древн.-верх.-немецк. nebul, древн.-английск. nifol 'темный'. Иероглифический лувийский местный падеж ti-pa-si ([tipas-i], где -i - показатель локатива), клинописный лувийский tap-pa-ši-i 'на небе' совпадает с литовским диалектным debesij, церковнославянским нєвєсн и русск. небеси ' на небе' и от него почти что не отличавшимся древнехеттским клинописным ne-e-pí-ši. В славянском и в древнеанатолийском совпадают и другие формы слова (в том числе родительный падеж множественного числа - среднехеттск. ne-pí-ša-an, старославянск. нєвєсъ, где -ъ восходит к сочетанию «гласный плюс носовой согласный», русск. небес), и его мифологическое и физическое (связанное с экологией) значение (сохраненный в анатолийских и балто-славянских языках исходный смысл позволяет предположить, что его изменение в других диалектах могло быть связано с переселением в области с иным климатом). Древняя мифологическая функция слова, вероятно, еще заметна в самой древней хеттской надписи Анитты, где предполагается оттеснение этого божества (Goedebuure 2007: 41; Иванов 2010: 30).

Имя другого важнейшего туземного бога в период слоя II - Perwa остается (в отличие от бога Неба) существенным и во все позднейшие периоды истории древнеанатолийской религии. В написанных местными жителями староассирийских текстах слоев I и II имена, содержащие это прозвание бога Perwa, принадлежат самым почитаемым лицам, как Pe-ru-wa na-si-ir Ka-ni-iš 'Perua, защитник Каниша'. Похожее имя бога встречается в архаичных хеттских перечислениях богов, славу которым поют «певцы Каниша». Родственные слова, как хеттск. peru(na)- 'скала, утес, глыба' (в том числе и скала - мать каменного чудовища Улликумми в хеттском переложении хурритского мифа), санскритск. parvata- 'гора', позволяют удостоверить первоначальную связь анатолийского имени бога с камнями и скалами как атрибутами праиндоевропейского бога Грома или Грозы, к которому восходит литовское имя аналогичного бога Perk-un-as, perk-unija 'гроза', древнеисландское Fjørgyn 'мать бога Грома' и. праславянское имя бога Грома, продолжавшееся в древнерусском Перунъ. В славянских языках слово относится и к каменным орудиям бога, которые он швыряет с небес (Иванов, Топоров 1974). Слово перуны в 
этом смысле долго сохранялось в языке классической русской поэзии. С приведенными литовским и древнеисландским существительными, в которых за корнем следовал суффикс *-йni-, сходно и славянское наименование места под Новгородом Пер-ынь (из *Peruni-), где экспедиция покойного Седова нашла остатки святилища бога Пер-уна. Хеттский бог Pirwa- (Perwa), как и праиндоевропейский и балто-славянский бог с родственным именем, связан с конями, которые везут его колесницу в соответствующих мифпоэтических текстах. Но в анатолийских традициях при сохранении древнего имени бога и некоторых его семантических связей (со скалами, с конями) утрачивается его первоначальная функция как бога грозы. В этой функции уже в древнеанатолийском диалекте времени староассирийских колоний, а затем и в хеттских и в лувийских текстах, выступает слово, которое некогда было одним из эпитетов этого бога как «Победителя». Сохранился в нем только суффикс, напоминающий о древнем имени бога (как в типологически сходном др.-греч. кє९ $\alpha$-vv-oí 'перуны, громовый удар'). Встречающееся в староассирийских текстах древнеанатолийское имя бога Грозы Таrhunи образовано от этого древнего эпитета с помощью суффикса -n-и-. Древнехеттское логографическое написание (d)IŠKUR (в самой древней надписи Анитты IM-un-ni 'бог Грома', соотносимый с «небом», название которого рассмотрено выше) передает этот древний эпитет, читавшийся как Tarh-unni и соответствовавщий лувийскому Tarhunt-, анатолийскому глаголу tarh-u'побеждать', и индо-иранскому *tr-v-ant- 'могучий, победительный'.

В собственных личных именах древнеанатолийского населения староассирийских колоний сохраняется также архаический общеиндоевропейский тип образования собственных имен (например, Šaptam-a-niga с предположительным значением '7-я сестра' или '7 сестер = Плеяды', Puhvel 1991², ср. сопоставляемое с этим именем написание 'единства из семи’ DVII.VII BI в хеттских списках богов) и названий мест (например, Ša-lá-ah-šu-a в тексте голенищевской коллекции ГММИ 1554, Янковская 1968, №64, строка 16, ср. комментарии там же: 27, 166, 225; ср. те же основы с другими суффиксами в хет. sall-(i)- + hašš-atar 'царский род') посредством сложения двух именных основ, связываемых соединительным тематическим гласным *-o- > анатолийск. - $a$ - (ср. родственное ${ }^{*}-0$ - в сложных

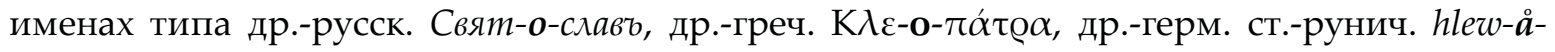
gåstiR). Этот тип словосложений принадлежит особому древнему анатолийскому диалекту (условно назовем его «диалект *-о)): он отличается от позднейшего состояния древнехеттского, лувийского и других северных и южных анатолийских индоевропейских языков. В них словосложение теряло свою древнюю роль (особенно в словобразовании) и при этом полностью исчез тип сложения с соединительной гласной. Его след можно видеть только в уже неразложимых древнехеттских сложных словах, как mеn- $a$ hhanda '(на)против, перед, по направлению к' < men-(i/a) 'лицо, щека' + -a<-*o- + hand-a 'в сторону' (древняя форма направительного падежа-директива от hant- 'передняя сторона, лоб'3).

${ }^{1}$ О связи этого индоевропейского термина с этрусским в контексте древнемалоазийского происхождения этрусков ср. литературу, обозреваемую в статье Иванов 2011: 77-79.

2 В пользу предположения о том, что в этом древнеанатолийском словосложении виден след древнеиндоевропейской астрономической терминологии, может говорить сравнение с лат. septem '7' (= др.-анат. šaptam) в septen-trion(es) 'созвезди(я)', septen-trio maior 'Большая Медведица', septen-trio minor 'Малая Медведица'.

${ }^{3} \mathrm{O}$ древности сложений с таким последним элементом свидетельствует название древнего города Puruš-ḩanda, но в нем нет соединительного гласного (первый элемент может быть прообразом этнонима пруссов, архаичность которого на основании других данных предположил В. Н. Топоров, и поэтому важен для проблемы балто-анатолийских диалектных связей). 
В том же древнем «диалекте *-о-», о котором мы знаем только по его следам в староассирийских текстах, архаический тип древнеанатолийских женских собственных имен представляет собой словосложение с последней (второй) основой -ne/ik/ga-; в соответствии с упомянутыми выше древними принципами индоевропейского словосложения перед этой основой выступало соединительное ${ }^{*}-0->-a-$. За первой именной основой следовал группа морфов -a-nig/ka. Основа сушествительного, в древнеанатолийском «диалекте *-о-» выступающая как nika, в древнехеттском отражена как nega- «сестра, кровная родственница еgо в его поколении», лув. -піуа-, она принадлежит к архаичным общим элементам анатолийского (древнехеттского и лувийского) словаря (с возможной ностратической этимологией, о чем ниже), с этнологической точки зрения допускающих интерпретацию ранней системы родства по типу омаха-кроу.

Открытие таких древних фрагментов индоевропейской речи, сохраненных в староассирийских текстах, представляет собой часть результатов широко проводимых исследований старинных текстов из Малой Азии. В настоящее время оказывается возможным расширить и достаточно далеко отодвинуть вглубь прошлого как давно занимавшую ученых (Gamkrelidze 1970) историю одиннадцати древних индоевропейских диалектов Малой Азии - северноанатолийских (хеттского, палайского, отчасти «диалекта ${ }^{*}$-о-» ${ }^{4}$ и лидийского, занимающих особое промежуточное место среди двух групп анатолийских языков) и южноанатолийских (лувийского в клинописном и иероглифических вариантах и непосредственно к нему восходящих языков античного времени - ликийского и становящегося отчасти понятным милийского, а также с трудом дешифруемого карийского и совсем мало известных сидетского и писидийского), так и рамки исторических свидетельств об индоевропейских языках в целом.

\begin{tabular}{l|l|l}
\hline \multicolumn{3}{c}{ Анатодийские языки II-I тыс. до н. э. } \\
\hline $\begin{array}{l}\text { северные (восточные): } \\
\text { тип сепtum }\end{array}$ & $\begin{array}{l}\text { Промежуточный } \\
\text { «диалект *-о-» }\end{array}$ & $\begin{array}{l}\text { южные (западные) } \\
\text { с различием * } k^{\prime} \text { и * } k\end{array}$ \\
\hline $\begin{array}{l}\text { хеттский (несийский) } \\
\text { палайский }\end{array}$ & лидийский & $\begin{array}{l}\text { лувийский клинописный } \\
\text { лувийский иероглифический } \\
\text { ликийский (А) }\end{array}$ \\
& & $\begin{array}{l}\text { милийский (Б) } \\
\text { карийский } \\
\text { сидетский } \\
\text { писидийский }\end{array}$ \\
\hline
\end{tabular}

Северно- и южноанатолийские языки целым рядом существенных грамматических и звуковых (фонологических) черт отличаются от всех других индоевропейских диалектов.

Время разделения семьи родственных языков можно определять методами глоттохронологии: как показал Суодеш, темп изменения базисного словаря (100 или 200 самых употребительных слов, в основном сохраняющихся при переходе от старшего поколе-

${ }^{4}$ По отношению к этому диалекту существует трудность разграничения пространственных и временных характеристик: по отражению древних велярных и палатальных его можно отнести к типу сеntum, но лексические элементы южноанатолийского вида (как в древнехеттской надписи царя Анитты топоним URUSa-la-ti-wa-ra < *sal-a-tiw-ar-: хет. šall-(i)- 'царский, великий' + -a- < *o- + лув. Tiwar- < *tiw-at- ‘бог Солнца' = хет. šiwat- 'день') могут указывать на наличие такого словосложения и в раннем предшественнике лувийского, имевшем другую систему фонем. 
ния к детям) поддается точному лексико-статистическому определению. Согласно глоттохронологическим вычислениям С. А. Старостина, основанным на 5-процентной (а не 14-процентной, как у Суодеша и прямых его продолжателей) константе изменения базисного словаря (Старостин 2007), им была получена в 2004 г. новая картина распада индоевропейского праязыка. Она согласуется в том, что касается соотношения хеттского и всех анатолийских, и с выводами многих других последних работ по индоевропейской диалектологии. По этим новым данным отделение хеттского от других индоевропейских языков произошло около 4670 г. до н. э. (для лувийского и соответственно праюжноанатолийского может быть предположено иное несколько более позднее время, но точное определение затрудняется ограниченным набором известной лексики, ср. детально Ivanov 2001). Между временем отделения хеттского от других диалектов индоевропейского праязыка и эпохой древнехеттских текстов XVI в. до н. э. прошло примерно 3 тысячи лет. Остальные языки продолжали развиваться как единое целое вплоть до выделения из них позднейших диалектов (Порциг 1960) начиная с пратохарского (отдельными лексическими изоглоссами сближающегося с лувийским). Но иные диалектные различия древнее, чем время распада индоевропейского праязыка и образования позднейших диалектных групп (как восточноиндоевропейская) или языковых союзов диалектов (как анатолийские) - мы видим их результаты уже в самый ранний период, доступный для исследования. К числу таких древнейших фонологических различий принадлежит изоглосса, по которой диалекты типа centum (латинская форма числительного 'сто', в классической латыни произносившегося как [kentum]) отличаются от диалектов типа satəm (древнеиранская авестийская форма того же числительного). Эта изоглосса проходит внутри восточноиндоевропейских языков, отделяя древнегреческий язык (тип centum) от армянского и индо-иранских (тип satəm).

В диалектах типа centum - северно-анатолийских: «диалекте - о-», хеттском, палайском, лидийском, западно-индоевропейских: кельтских, италийских, в том числе латинском, а также германских, иллирийских, в частности, месапском; восточноиндоевропейском древнегреческом, македонском, фригийском, на котором говорили на Балканах и потом в Малой Азии, и в известном в Восточном Туркестане тохарском сохраняется древнее противопоставление велярных фонем типа * $k$ и лабиовелярных типа ${ }^{*} k^{w}$ при устранении палатальных фонем типа * $\hat{k}$, в праиндоевропейском противостоявших двум первым типам; тогда как в диалектах классического типа satəm - восточноиндоевропейских индо-иранских (восточно- и западно-иранском, месопотамском арийском, нуристанском, дардском, индо-арийском) и армянском, а также в балтославянских, албанском и родственных ему палеобалканских фракийского типа - сохраняется древнее противопоставление велярных фонем типа *k и палатальных фонем типа * $\hat{k}$, изменяющихся в аффрикаты и потом фрикативные, при почти полном устранении лабиовелярных типа * $k^{w}$, а в южно-анатолийских - лувийском, ликийском, карийском - сохраняется древнее противопоставление велярных фонем типа * $k$ и палатальных фонем типа *k, изменяющихся в аффрикаты и потом фрикативные, и древнее противопоставление велярных фонем типа * $k$ и лабиовелярных типа $k^{w}$. Таким образом в южноанатолийском сохраняются, как отчасти в армянском и в албанском по гипотезе Педерсена, следы фонологического противопоставления всех трех групп (велярных, палатальных и лабиовелярных) фонем, восстанавливаемого для самого раннего состояния, хотя в южноанатолийском, как и в других диалектах satəm, палатальные фонемы и меняют свой фонетический характер, превращаясь из смычных в аффрикаты и фрикативные, а многие слова с лабиовелярными принимают новый облик, устраняя эти фонемы. 
Открытие различия между северноанатолийскими и южноанатолийскими языками по этой изоглоссе, как и обнаружение centum-ного характера тохарских языков VIIVIII вв. н. э. в Китайском Туркестане, существенно меняет представление об этой стороне прошлого индоевропейских диалектов. Ни в одном из диалектов древняя картина не сохранена полностью. Многие лингвисты полагали, что первоначальное противопоставление этих типов было связано с простым географическим размежеванием восточных и западных диалектов. Современное состояние наших знаний скорее говорит в пользу предположения, что развитие по типу centum наблюдается в языках на периферии (маргинальных) - кельтских, тохарских, северно-анатолийских ${ }^{5}$, что по закономерностям, выявленным ареальной лингвистикой, говорит в пользу сохранения в них архаизма (в частности, в отсутствии движения палатальных в сторону аффрикат и спирантов).

В ту эпоху, когда на территории Малой Азии представлены две интенсивно друг с другом контактировавшие (и благодаря длительному многовековому взаимодействию образовавшие в конце концов единый анатолийский языковой союз), но различающиеся по только что описанной ранней изоглоссе и по некоторым другим признакам группы языков - северно-анатолийская и южная (Ivanov 2001), письменные свидетельства о других индоевропейских диалектах относятся только к двум ареалам, непосредственно примыкающим к Малой Азии: на Западе к микенскому древнегреческому в Греции и на Крите, а на Востоке к месопотамскому арийскому, функционировавшему (вместе с неиндоевропейским хурритским, согласно открытию И. М. Дьяконова и С. А. Старостина родственным северо-кавказским языкам) в качестве одного из главных языков верхушки населения в государстве Митанни в северной Сирии. Месопотамский арийский известен по словам и словосочетаниям в хеттском трактате о коневодстве митаннийца Киккули, найденном в архиве в хеттской столице Хаттусасе (Богаз-Кале), и по именам богов в хеттско-митаннийском государственном договоре в том же архиве. Древнегреческий и месопотамский арийский (один из ранних индоиранских диалектов, близкий к индо-арийскому) относятся к восточноиндоевропейской группе диалектов, куда входит и древнеармянский язык, достаточно рано распространенный в том же ареале, судя по многочисленным заимствованиям в нем из хурритского и урартского (который происходит из сравнительно позднего хурритского диалекта). Восточно-индоевропейские языки по своей глагольной системе и некоторым другим грамматическим особенностям образуют отличную от прочих родственных диалектов группу.

Ко времени письменной фиксации индоевропейских языков во II тыс. до н. э. внутри восточноиндоевропейских языков связи были разорваны таким образом, что centum-ный древнегреческий язык оказался на западе - в Греции, куда по данным археологии и лингвистики (Carruba 1995) его носители вероятно переселились в предшествовавшем тысячелетии из Малой Азии, а близкий к satam-ному типу (по развитию древних палатальных в аффрикаты и фрикативные) южноанатолийский (по данным топонимии и

${ }_{5}^{5}$ Маргинальное положение для северноанатолийского можно предположить при юго-восточном приурочении индоевропейской прародины - существенно восточнее или южнее Анатолии (по ГамкрелидзеИванову в отличие от Ренфрю, см. ниже). Но топология (абстрактная схема отношений между диалектами, которую теперь пробуют описать и методами кладистики, выработанными в биологии) внутри раннего индоевропейского праязыка нуждается в специальных исследованиях. В частности, результаты работы Ёсида, показавшего зависимость исчезновения - $r$ в хеттских глагольных формах от акцентуации, позволяет вернуться к сходным предположениям Фортунатова о связи исчезновения этой фонемы с ударением или тоном. Тем самым возникают новые возможности истолкования отношений между диалектами, в глагольных (медиопассивных и перфектных) окончаниях которых существенно наличие (возможно как архаизма) или отсутствие морфа, выражаемого посредством сочетания этой фонемы с другими. 
мифологических терминов вероятно бывший древним субстратным языком населения Греции) распространился на Востоке в Малой Азии, где образовал языковой союз с centum-ным северноанатолийским. В результате происшедшей «рокировки» - перемены мест обитания - носителей древнегреческого и южноанатолийских языков были разорваны связи между греческим и другими восточно-индоевропейскими языками. Эти перемещения предполагают широкое использование водного транспорта (хотя переход из Малой Азии в Грецию и обратно был возможен и по суше до образования проливов на заболоченных местах перешейка, потом уничтоженного). Через тысячу лет распространение западно-индоевропейских (Порциг 1960; «древнеевропейских» по терминологии Краэ) языков на Запад Европы и индо-иранских и тохарских языков на Восток предполагает использование колесных повозок, запряженных конями (ср. ниже об этой проблеме).

На протяжении следующей тысячи лет эта семья языков распространилась от Британских островов на Западе и Скандинавии на севере до Синьцзяна (Восточного Туркестана) на востоке и на юге до Инда.

Из отдельных ветвей индоевропейской семьи языков к концу античного времени и в начале средних веков наибольшего распространения достигли среднеиранские языки.

Вероятно, что движение на Восток в определенный период сделало иранские языки основными не только для Средней Азии и будущего Восточного Туркестана, но и для еще более обширной области к востоку и северу (языковые тексты в этих ареалах пока не найдены за исключением Восточного Туркестана). Постепенно, однако, из этих областей иранские (и другие индоевропейские, в частности, тохарские) языки вытеснены при движении с Востока китайцев и кочевников - тюрков и монголов.

Какими путями сложилась современная и более ранняя картина распространения индоевропейских языков? Откуда могло начаться движение и какова могла быть исходная территория прародины, на которой обитали носители праиндоевропейского языка перед его распадом на рубеже VI и V тыс.? Рассмотрим вслед за схемой Мэллори 1997 (карта 1) модели «прародины» - территории распространения диалектов индоевропейского праязыка, после разделения ветвей которого постепенно осуществилось их движение по Евразии.

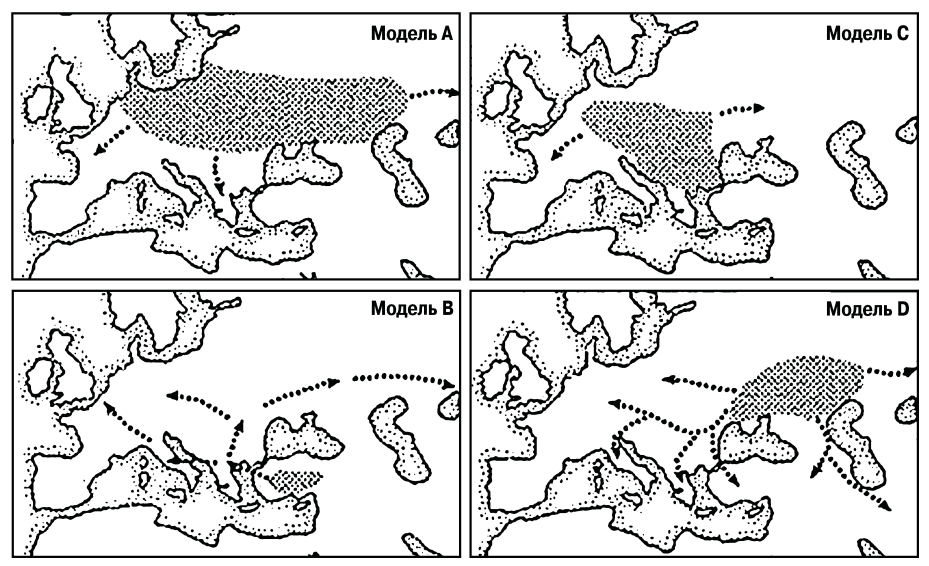

Карта 1. А: северо-европейская модель; В: южно-анатолийская модель Ренфрю; С: центральноевропейская модель; D: волжско-уральская модель.

Первая из четырех (по классификации Мэллори) основных альтернативных моделей является той, которая в первоначальном виде была традиционной для прежней 
школы индоевропеистики. В ней речь шла о территории, включающей Северную Германию (эта модель была предложена до выявления фактов анатолийских и тохарских языков, с которыми ее трудно согласовать для раннего периода). В других моделях сходного типа реконструкция вела вслед за Шрадером к более восточной территории Восточной Европы (одно время в пользу этой локализации прародины приводились данные о массовости остатков лошади в Дереивке на Днепре, но единственный конский череп со следами якобы от удил на зубах оказался неверно датированным). В последнее время многие думают о еще больше отодвинутой к Востоку древнеурало-волжской прародине, приурачиваемой к находкам в Аркаиме-Синташте (ср. Григорьев 1999; Иванов 2004), действительно важным для всей проблемы, но тоже относительно более поздним, и, наконец, предложенной Ренфрю (отчасти в развитие модели Гамкрелидзе - Иванова) локализации прародины в Юго-Восточной Анатолии (с этим был склонен согласиться в конце полемики с Гамкрелидзе - Ивановым также и И. М. Дьяконов); позднее Ренфрю и Дьяконов рассматривали юг Балкан как возможное уточнение этой модели. Ренфрю принимал выдвинутый авторами книги Гамкрелидзе - Иванов 1984 тезис об относительно позднем времени проникновения неолитических достижений в сельском хозяйстве в Европу. Сходная точка зрения высказывается и в других новейших работах (Bouckaert et al. 2012). Но устанавливаемая по глоттохронологии лексико-статистическая дата распада праязыка около 5000 лет до н. э. оказывается более поздней, чем начало проникновения результатов неолтической революции в Европу. Отдельные достижения и связанные с ними слова могли быть усвоены до массовой индоевропеизации западных областей Европы. Поэтому отпадает и основание для приурочения прародины к западу Анатолии, а не более восточным и южным областям.

Большинство рассмотренных вариантов предполагает продвижение индоевропейцев в Среднюю Азию и Индию с запада. Но в последнее время Николз предположила обратное направление переселения из Средней Азии (Согдианы, по близости от Аральского моря, где Бенвенист и другие иранисты видели древнюю колыбель иранцев в Eran Vež, авест. Airiianam Vaējō 'арийский простор'). Переселения из Средней Азии (возможно связанные с растущей аридностью) едва ли могут быть отнесены к раннему времени. Сходные возражения могут быть сделаны и по поводу часто теперь высказываемых предположений относительно автохтонности индоариев в Индии.

Каждая из приведенных моделей и их многочисленных вариантов соответствует одному из относительно поздних этапов расселения, но не выдерживает проверки лексико-статистической лингвистической хронологией распада праязыка и археологическими и генетическими данными о путях и времени переселения отдельных более древних групп, говоривших на индоевропейских диалектах, и их вероятных предшественников (ср. также Сафронов 1989).

Следует изучить позднейшие тенденции расселения, в частности, в контексте рассматриваемой ниже хронологии использования коней и колесных повозок как способа переселения, что позволяет датировать наиболее дальние пути миграции на восток и на запад временем существенно более поздним, чем отделение северно- и южноанатолийских, а затем и тохарских языков. Кажется возможным для первых столетий после распада праязыка думать о разделении родственных диалектов, на которых говорят в соседних горных и предгорных районах с затрудненной коммуникацией. При реконструкции причин переселения наряду с социальными демографическими факторами - последствиями результатов неолитической революции и возникновения производящего хозяйства - следует учитывать и такие экологические, как изменение бассейна образовавшегося Черного моря (циркумпонтийский характер территории распространения индоев- 
ропейцев при обсуждениях подчеркивал Н. Я. Мерперт6), а также повышение аридности среднеазиатского ареала.

Докладчики предложили (впервые в докладе в Москве в 1972 г., затем в серии статей и в книге Гамкрелидзе - Иванов 1984, Gamkrelidze, Ivanov 1990; 1995; Gamkrelidze 1990; 1994) локализацию прародины на Ближнем Востоке на стыке современной Сирии, юговосточной Турции и северного Ирака (близко к пространству между озерами Ван и Урмия). Эта модель сопоставляется с юго-западно-анатолийской, несколько позднее предложенной Ренфрю.

Рассматривая доводы, выдвигавшиеся за последние четверть века за и против северо-месопотамско-ближневосточной территории прародины индоевропейцев (Иванов 2004; Ivanov 2007), следует прежде всего отметить исключительное значение для ее доказательства проблемы праязыковых заимствований. Исследования последних нескольких десятилетий (особенно Г. А. Климова и С. А. Старостина) много сделали для выяснения массового характера заимствований, свидетельствующих об интенсивных культурных контактах носителей индоевропейского праязыка с их соседями, говорившими на праязыках окрестных семей языков- северо-кавказской (в этот ранний период включавшей и хурритский язык Северной Сирии и поэтому безусловно распространенной не только на Кавказе, но и существенно дальше на юго-запад от Закавказья), картвельской и семитской.

Типологические сопоставления пракартвельского с праиндоевропейским были более чем полвека назад предложены в совместной работе Г. Мачавариани и Т. Гамкрелидзе и развиты в последующих исследованиях. Индоевропейские (и.-е.) заимствования в картвельском (Климов 1994, 1994а'7), в последующих работах Старостина отделенные от предполагаемых ностратических элементов, которые могли быть унаследованы, включают такие слова, как: картвельск. ${ }^{*}$ ankes- 'рыболовный крючок' > грузинск. ankes-i : и.-е.

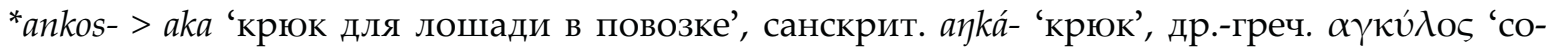
гнутый', лат. uncus, др.-англ. angul; картвельск. *tel- 'поросёнок' : и.-е. *tel- 'молодое животное'; картвельск. *usxo- ‘бык для жертвы’ : и.-е. ukwso- ‘бык’ (Klimov 1998: 195-196). Значительное число таких слов относится к сельскохозяйственной терминологии. Индоевропейско-северокавказские общие культурные термины, изученные С. А. Старостиным (Старостин 2007), включают такие имена домашних животных, как сев.-кавк.

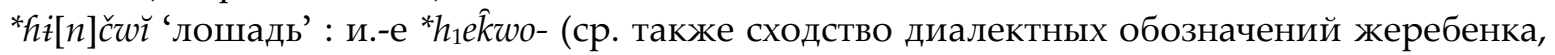
сев. кавк. *farnē и и.-е. * polo-s, и некоторых других коневодческих терминов, заимствованных из одной семьи в другую, как сев.-кавк. *gwä̆lV 'конь', сопоставимое с лат. caballus 'paбочая лошадь' и вероятно родственными формами в древнегреческом и хеттском, Ivanov

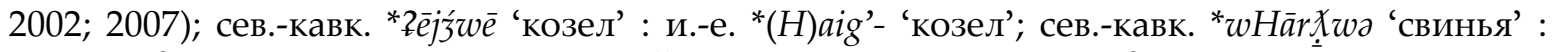

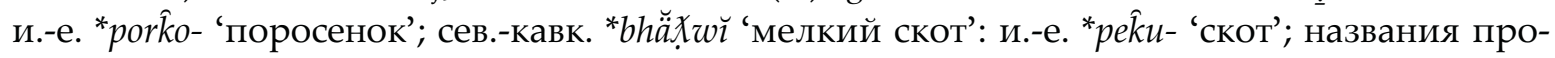
дуктов, изготовлявшихся из животноводческих материалов - сев.-кавк. *גِwā̄ni 'шерсть' :

${ }^{6}$ Н. Я. Мерперт, светлой памяти которого мы, как и другие авторы номера, посвящаем нашу статью, отмечал, что древнеземледельческие культуры раннебалканского ареала в V тыс. до н. э. обнаруживают вероятное влияние анатолийского сельского хозяйства. Они опережают в развитии производящей экономики более северные центрально- и восточноевропейские группы населения, достигающие сопоставимых успехов только в следующем тысячелетии (Мерперт 1988: 27; Иванов 2004: 54 и примеч. 39).

${ }^{7}$ В раннем картвельском можно различить относительно более поздний слой слов, имеющих индоевропейские соответствия времени после утраты ларингальных, и более древний, в котором есть соответствия индоевропейским ларингальным. Часть слов последней группы с точки зрения ностратического сравнения может быть отнесена к праностратическому наследию. В работах Старостина эти слова отделены от значительной группы общих древних заимствований, являющихся бесспорными; Иванов 2004: 66; Ivanov 2007. 


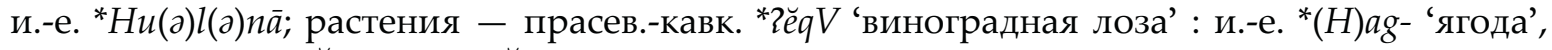
сев.-кавк. * $ћ w V g a b \breve{V} /$ * $h w V b a g \breve{V}$ 'вид злаков > овес' : и.-е. * $(H) a u i g$ 'овес'; орудия - сев.-кавк. “HwVrV ‘мельница, жернов’: и.-е. *gwerən 'жернов’; сев.-кавк. *ničo 'нож, серп’: и.-е. nsi-

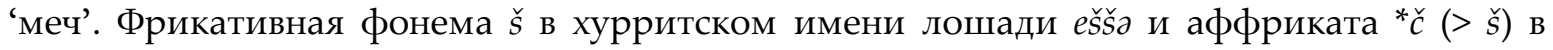
формах других северо-кавказских языков соответствует индоевропейской палатальной смычной *kै, ставшей аффрикатой *̌̌ и потом фрикативной $̌ / s$ в индоевропейских диалектах типа satam. Сходные фонетические изменения представлены в других заимствованиях, собранных Старостиным. Он предположил, что они большей частью заимствованы из прасеверо-кавказского или его диалекта в праиндоевропейский. Типологические выводы относительно вероятных законов звуковых изменений скорее говорят об обратном направлении заимствований: в таком случае в этот период уже осуществлялось изменение палатальных в аффрикаты и фрикативные по типу satam ${ }^{8}$. Но в любом случае факт заимствования несомнен и однозначно определяет вероятное местоположение индоевропейской прародины рядом с прасеверокавказской.

Культурные термины, которыми обменивались древние народы, говорившие на праязыках этих семей, показывают, что они входили в область быстрого распространения достижений неолитической технической и экономической революции. Вместе с тем кажется возможным поставить вопрос о том, что наряду с другими причинами (в частности, экологическими) именно резкое увеличение возможностей производящего хозяйства вело к демографическому взрыву, способствовавшему необходимости поиска новых территорий и миграциям. Особый интерес для исследования проблемы способов переселения представляют названия, относящиеся к транспорту, в частности, колесному: хеттское hurki- = тохарское A wärk-änt- соответствует варианту с satəm-ным отражением палатального и потерей начального ларингального в иероглифическом лувийском (CURRUS)wa/i+ra/i-za-ni-na, вин.п. мн.ч. 'колесниц'. Родственный заимствованный термин huluga-nn-i с хурритским постпозитивным артиклем -nпi встречается в староассирийских текстах начала 2 тыс. до н. э. и позднее в хеттских текстах. Он заимствован из источника, общего с сев.-кавк. *hwalkw- > чадоколобск. аварск. hork- 'повозка', лакск. harkw 'ось колеса телеги', зап.-кавк. *kw: > адыг. kwə 'повозка' (в этом случае следы развития по типу satəm есть в южноанатолийском, а не в северо-кавказском, и источник заимствования скорее в последнем).

В посмертно напечатанной статье С. А. Старостина собрано значительное количество вероятных заимствований из индоевропейского в семитский (Старостин 2007: 821826, о возможных уточнениях ср. в комментарии там же: 895). В качестве примера еще одного культурного заимствования индоевропейского слова в семитском можно рассмотреть индоевропейское название 'земли' *dheg'hom> хеттск. tekan, род.п. tagnaš', тохар. А tkam. Эта основа входит в такие анатолийские имена богов, как хеттск. Dagan-zipa 'дух Земли’ (буквально «Земля как личность»). Он вероятно была заимствована в (запад-

8 Правда, Старостин (в устной форме) возразил, что этот типологический аргумент (малая вероятность изменения спирантов и аффрикат в палатализованные заднеязычные смычные) имеет силу при развитии в рамках одной языковой традиции, а в рассматриваемом случае мы имеем дело с заменой при заимствовании из северокавказского отсутствовавших в индоевропейской фонетической системе аффрикат на наиболее сходные из имевшихся фонем, т. е. на палатализованные (Кулланда 2008: 674).

9 В клинописном лувийском * $g$ ’h исчезло и слово превратилось в tiya-. В более поздних иероглифических лувийских документах сирийско-южноанатолийских князей их писцы стилизовали тексты как бы в духе более древней имперской хеттской традиции, чем вероятно объясняется перенятие из хеттского формы takam-i «земля», не отвечающей законам лувийской исторической фонетики. 
но-)семитский, где используется в качестве имени бога Dagan ${ }^{10}$. Стоит отметить,что это же индоевропейское название 'земли' было заимствовано в пракартвельский, где соответствующие слова использовались в значении 'плодородная (черная) почва' (Klimov 1998: 41).

Рассмотрев семитские слова, в древний период заимствованные из индоевропейского, С. А. Старостин приходил к выводу: «мы имеем дело здесь с заимствованиями либо из пранатолийского, либо из исчезнувшей ветви индо-хеттского» («we may deal here either with the loans from proto-Anatolian or from an extinguished branch of early IndoHittite», Старостин 2007: 825). Он считал наиболее вероятным объяснением заимствований этого рода из индоевропейского в семитский, картвельский и северо-кавказский приурочение индоевропейской прародины к северу Древнего Ближнего Востока в духе нашей гипотезы и сходных выводов А. Б. Долгопольского (там же: 825-826 и 819; ср. Dolgopolsky 1988) ${ }^{11}$.

Взаимодействие ранних диалектов праязыков индоевропейской, семитской, картвельской и северокавказской семей привело к образованию подобия языкового союза, обладающего кроме общего словаря культурных заимствований (Старостин 2007: 256264, 289-358, 806-826) рядом фонологически и грамматически сходных черт (Гамкрелидзе, Иванов 1984; Gamkrelidze, Ivanov 1995; Gamkrelidze 1995; 2006; Иванов 2004: 46-47 с дальнейшей литературой).

Когда была выдвинута гипотеза о ближневосточной локализации прародины, ее критики обращали внимание на то, что предполагаемое время и место существования индоевропейского праязыка близко к зоне древнейших письменных культур и поэтому можно было бы ждать отражения соответствующих фактов в памятниках письменности.

В настоящее время можно с большей определенностью привести некоторые данные этого рода. Прежде всего это указанные выше индоевропейские элементы в староассирийских текстах. Великий иранист Хеннинг предположил, что предки исторических тохар - особой ветви индоевропейцев - составляли правящую династию народа кутиев. Кутийские племена вторглись в Месопотамию около 2350-2200 г. до н. э. В работе, написанной после нашей совместной книги, мы развили идею Хеннинга. Он опирался главным образом на сближение древнеближневосточных этнонимов Guti и Tukri, с одной стороны, центральноазиатских наименований «кучанской»и «тохарской» языковых групп, с другой ${ }^{12}$ (Gamkrelidze, Ivanov 1990-1991). Кутийские владыки правили частью Месопотамии.

${ }^{10}$ Гипотеза об этом заимствовании была высказана почти одновременно несколькими учеными, см. Singer 2000. О боге Dagan в Сирии см. Feliu 2003; Crowell 2001. К числу семитских слов, предположительно сопоставляемых с этим именем бога (см. о его этимологии Renfroe 1992: 91-94), принадлежит название 'рыбы' *dag-, которое тоже не имеет корневой семитской этимологии и может быть сопоставлено с праиндоевропейским * $d^{h} g^{h}$ ' u- (Starostin 2007: 823, № 575; об этом сравнении см. там же: 762). У этого слова такая же акцессивная структура («спирант Бругманна», см. Гамкрелидзе, Иванов 1984; Gamkrelidze, Ivanov 1995; Иванов 2007: 344-366), как у названия земли. Семантическая связь имени (бога) Земли и рыбы возможна судя по распространенности мотива (в том числе древнеиндоевропейского) рыб как животных подземного мира.

${ }^{11}$ В качестве альтернативного объяснения, которое ему самому не казалось надежным, Старостин упоминал допущение таких средств передвижения по морю, которые сделали бы возможным контакт раннего семитского с другими языковыми семьями. Эта гипотеза пока не находит археологического подтверждения.

${ }^{12}$ Ср. позитивное принятие гипотезы Хеннинга: Thomas 1985: 14-17. В своей статье 1965 г. о тохарах как «the first Indo-Europeans in history» Хеннинг предположил, что древнее произношение китайского названия юэ-чжи = Yuezhi (= кучан = тохар) может быть приблизительно восстановлено как *Gu(t)-t’i и предпо- 
В пользу предположения Хеннинга можно привести некоторые возможные этимологии имен кутийских царей (ср. Гамкрелидзе, Иванов 1989; Gamkrelidze, Ivanov 2006).

К более раннему периоду относятся тексты из города Эблы, в которых есть топонимы и личные имена индоевропейского происхождения (Иванов 2004; Ivanov 2007); Гельб относил индоевропейский к числу языков Эблы.

Согласно гипотезе, выдвинутой Уиттакером, в древнейших предклинописных глиняных табличках из Южной Месопотамии со 2-й половины IV тыс. до н. э. представлено несколько десятков (если не больше) слов архаического индоевропейского диалекта (Whittaker 1998; 2004). Некоторые из этимологий, предложенных Уиттакером, представляются вероятными, например, hиніп 'орел' (засвидельствовано уже в шумерском словарном списке в Эбле, А 11/620), тождественное хетт. hara-n-, др.-греч. о̆ $\iota^{13}$. Некоторые предполагаемые грамматические черты «евфратского» индоевропейского языка подтверждаются рядом параллелей: употребление конечного суффикса - $t$ в конце именных форм сходно с окончанием среднего рода имен в лидийском и в некоторых индоевропейских местоименных формах; роль суффикса -и- в «евфратских» прилагательных напоминает такую же анатолийско-балтийскую изоглоссу (Puhvel 1982; Erhart 1995; Gusmani 1968).

Согласно этим предположениям, задолго до документированных индоевропейских имен и слов в староассирийских текстах рубежа III и II тысячелетий, о которых речь шла выше, существуют гипотетические следы пребывания носителей индоевропейских диалектов на Ближнем Востоке еще в двух предшествующих тысячелетиях.

Выявлению более ранних периодов предыстории праиндоевропейского языка может способствовать его сравнение с родственными ностратическими языками. Эта новая область языкознания, основанная в нашей стране В. М. Илличем-Свитычем, успешно развивается. Упомянутое выше хеттское слово hant- 'передняя сторона, лоб' как название части тела ('лба, носа, профиля лица') *H(o)nt- имеет соответствия не только в древних индоевропейских языках, но и в уральском (финно-угорск. *оńс́́́ 'лоб') и афразийском (древнеегипетском, что около 80 лет назад предположил гениальный безумец Форрер, и чадском) и возводится к древнейшим элементам хеттской и индоевропейской лексики ностратического происхождения. В качестве другого примера можно назвать приведенную выше древнеанатолийскую основу, обозначавшую родственницу в поколении ego. Передававшийся в хеттской клинописи несдвоенным написанием интервокального смычного $-g / k$ - индоевропейский звонкий придыхательный заднеязычный в лувийском исчезал: хеттск. апnа-пеga- 'двоюродная сестра' сответствует лувийск. anna-niya-[mi] (первая половина сложения представляет собой анатолийское имя «мать» в несвязанной форме лувийск. апn-i, отвечающее ономатопоэтическим формам «детских» имен родства в других языках), хеттск. пеg-na 'брат' - лувийск. nana-sr-i 'сестра': к соответствующему лувийскому названию сиблинга - брата или сестры - присоединен последний элемент, обозначающий в индоевропейском женщину. Следовательно, исходная основа, близкая к хеттской и к форме в «диалекте *-о-», восстанавливается для праанатолийского (или, если считать два анатолийских языка, где она представлена, разными индоевропейскими диалектами, то и для праязыка, из которого они происходят). Эта общеанато-

ложительно связано с именем кутиев 'Guti'. Однако китайский этноним 月氏 мог звучать и *ngi wāt-tĭĕg, так что это допущение Хеннинга остается спорным: Mallory and Mair 2000: 281-282; см. далее: Hill 2004 ; Liu 2001.

${ }^{13} \mathrm{C}$ этой точки зрения некоторые подобные соответствия, которые мы в нашей книге (вслед за другими авторами) рассматривали как культурные слова, общие у шумерского с индоевропейским и иными языками, могут считаться изначально индоевропейскими «евфратскими», ср. о шумерск. GIGIRA 'колесница’ Whittaker 1998: 144; Frayne 1992: 21. 
лийская основа восходит к ностратическому: Чоп предложил возводить ее к индоуральскому, сопоставляя с венгерск. пӧ и другими финно-угорскими и самодийскими названиями 'женщины'; более точное соответствие обнаруживается в алтайском *nek' $V$ > тунгусо- маньчжурск. *neku 'младший родственник (сестра, брат)' > негидальск. нәхун 'двоюродный младщий брат, двоюродная младшая сестра, племянник, племянница, брат или сестра мужа или жены, младше говорящего; младший, младшая’, дравид. nāg'младшая женщина' < ностратич. * $n V k V$. Слова с ностратическими этимологиями, отсутствующие в других индоевропейских языках, могут считаться особыми архаизмами анатолийского прадиалекта или двух прадиалектов- северно- и южно-анатолийских. В данном случае вероятен и семантический архаизм, позволяющий предположить отражение в названии младшей родственницы типа родства, позднее исчезающего или перестраивающегося (что влекло и изменение терминологии родства).

Можно рассчитывать на значительное расширение наших знаний о самом раннем периоде существования индоевропейского праязыка на основе ностратического сравнения с другими праязыками внутри той же макросемьи ${ }^{14}$.

Для сопоставления приведенных выше выводов, подтверждающих языковыми заимствованиями ранний срок реконструкции связей между праязыками и их носителями, с данными археологии и генетики (а также возможно и сравнительной мифологии в духе работ Ю. Е. Березкина) важны прежде всего хронологические соображения.

При анализе на материале разных современных популяций соотношения лингвистических данных с генетическими обращает на себя внимание возможность и необходимость выделения разных хронологических слоев. При синхронном сравнении выявляется значительное сходство территориально смежных групп населения.

Такие выводы популяционной генетики напоминают обобщения ареальной лингвистики. Для формулировки времени начала работ по лигвистической географии, по которой, двигаясь от Парижа до Рима, можно обнаружить сходство каждого из вариантов романской речи в двух соседних населенных пунктах, вероятно сопоставление с аналогичными данными о генетических особенностях популяций, живших достаточно долго по соседству друг от друга. Типологические сопоставления всех языков мира, включенных в WALS 2005, подтверждают вероятность образования лингвистических зон, характеризующихся наличием одних и тех же признаков, в географически смежных ареалах.

От такого рода объединений типа «языковых союзов», сформировавшихся в относительно близкое время на соседних или смежных территориях, отличаются сходства языков, происходящих из диалектов одного праязыка ${ }^{15}$. При исследовании «коэволюции» явлений, изучаемых в лингвистике и в генетике, делались попытки прямо соотнести результаты сравнительно-исторической реконструкции процесса распада праязыков с картиной генетической предыстории геномов соответствующих групп населения ${ }^{16}$. В работах последнего времени преобладает подход, предполагающий возможности последующего (часто неоднократного) смешения разных в хронологическом отношении групп.

${ }_{14}$ В связи с обсуждением местонахождения прародины отметим, что для праиндоевропейского Иллич-Свитыч, как и Долгопольский (Dolgopolsky 1988), помещал ее на Ближнем Востоке.

${ }^{15}$ Кн. Н. С. Трубецкой был первым, кто попробовал применить понятие языкового союза для интерпретации сходств (в частности, фонологических) индоевропейского праязыка с праязыками географически близких семей.

${ }^{16}$ Ср. гипотезу о связи гаплотипа Y-ДНК R1a1a (M17) с индоевропейцами, высказанную в работе Zerjal 1999 и развитую и обсуждаемую в значительном числе работ, в том числе и на фоне широких сопоставлений с лингвистическими и археологическими данными. 
Темпы вероятной генетической (в принципе чрезвычайно медленной, хотя и зависящей от таких внешних факторов, как вирусы) и лингвистической эволюции (во всяком случае, той, которая измерима методами глоттохронологии) совершенно различны. За 10000 лет основная часть базисного (100- или 200-словного словаря) может измениться самым радикальным образом, а гаплограммы не покажут столь существенных перемен. Вопрос относительных темпов развития, изучаемый отчасти вслед за Суодешем или в духе статистического подхода, выделяющего самые употребительные слова (ср., например, Pagel et al. 2007), в очень малой степени выяснен по отношению к другим уровням языка кроме базисного словаря. Внутри лексики существует для многих групп языков почти стабильная часть, в отличие от базисного словаря выучиваемая не в раннем детстве и поэтому не подверженная лексикостатистическим закономерностям. Она связана с некоторыми чертами наследуемой культуры и в случае ее непрерывного развития может наследоваться длинным рядом поколений взрослых говорящих 17 (к изученным примерам сохранения терминов на протяжении 5 тысяч лет относится, например, лексика описаний солнечного и лунного затмений в северозападнокавказских языках и в хаттском). Длительность передачи одних и тех же фонологических соотношений эмпирически общеизвестна. В качестве изученного примера сошлемся на системы фонем цыганских диалектов, через пракриты возводимых к древнеиндийскому, т. е. почти неизменных на протяжении больше полутора тысячи лет ${ }^{18}$, при огромности числа заимствований, отражающих последующие контакты с другими языками. Кажется возможным и сохранение многих грамматических черт (отчасти это исследовано Моргенстьерне в работе об индоевропеизмах современных языков). Более детальное изучение степени изменчивости разных уровней языка могло бы помочь и в сопоставлениях с молекулярными часами: хотя их формальная структура близка к глоттохронологии, реальные темпы развития и его причины весьма различны.

Кроме того, часто наблюдаемый переход всего населения на другой язык (что неоднократно происходило в Европе в историческое время ${ }^{19}$ и предполагается для доистории) соотносится не с эволюцией древнего генома из-за отдельных мутаций, а со сменой всего набора признаков. Хронологическая сложность сопоставлений выявляется и при сравнении элементов материальной и духовной культуры, обнаруживаемых археологами (а также исследователями сравнительной мифологии и смежных областей культурной антропологии), с лингвистическими и генетическими реконструкциями ${ }^{20}$. В качестве

${ }^{17}$ Из хорошо изученных в индоевропеистике фактов этого рода сошлемся на так называемый «индоевропейский поэтический язык». В древнеиндийском и авестийском, с одной стороны, в раннем древнегреческом, с другой, сохранилось очень большое число слов и словосочетаний этой предполагаемой особой разновидности («речевого жанра») реконструируемого восточноиндоевропейского праязыка.

${ }^{18} \mathrm{O}$ подтверждении этой достаточно давно установленной лингвистической даты новыми генетическими данными о начале отделения носителей працыганского от говоривших на других средне-индоарийских диалектах около 1500 лет назад ср. Mendizabal et al. 2012.

${ }_{19}$ В таких хорошо изученных случаях, как смена кельтских, западно-германских, скандинавских и романских элементов в языковой истории Англии, обнаруживается и еще одна трудность: наслаиваются друг на друга элементы систем, изначально родственных (ярко выражено это явление в соотношении древнеперсидских и мидийских элементов в истории персидского языка, восточно и южнославянских - в истории русского языка и т.д.).

${ }^{20} \mathrm{~B}$ качестве наглядного примера можно привести полное отсутствие археологических данных о древнейшем морском транспорте при вероятии его реконструкции для очень раннего времени по генетическим соображениям и при спорности большинства возможных лингвистических сравнений, предполагающих вероятность реконструкции, например, общеиндоевропейского названия судна, сходного с семитским. 
примера, важного для нашей темы, отметим упомянутое выше несовпадение предполагаемой археологической датировки проникновения неолитической революции в Европу и соответствующих данных о названиях предметов, с ней связанных. Поэтому выводы, формулируемые в настоящее время (ср. о доводах в пользу анатолийского приурочения прародины Gray, Atkinson 2003; Bouckaert et al. 2012), остаются пока гипотетическими.

Исключительный интерес представляет сравнительное изучение генома тирольского «ледяного человека», погибшего в Альпах около 5300 лет назад (т. е. в период, соответствующий по лингвистической шкале поздним этапам распада праиндоевропейского после отделения предков хеттского и лувийского). Предполагается, что наибольшую близость обнаруживают гаплограммы, характеризующие современных жителей Сардинии. Поскольку предполагается исконное родство этих последних (и части обитателей Корсики, входящих в ту же генетическую группу) с древним трансальпийским населением (Keller et al. 2012), кажется возможным сопоставление с аналогичными данными о тирренских языках этих же мест Европы, в том числе об альпийском ретском языке (см. библиографию и обсуждение в Иванов 2011: 94-95), родственном сардинскому субстратному, скорее всего, неиндоевропейскому. Генетики, изучавшие «ледяной» геном, полагают, что он относится к посленеолитичекому земледельческому населению, представленному в это время и несколько позднее в Болгарии и в в Швеции (Sikora et al. 2012) и существенно отличному от современного населения континентальной Европы. Но непереносимость лактозы у взрослого, отраженная в геноме «ледяного человека», могла бы указывать и на то, что с древними носителями неолитического скотоводства он непосредственно генетически не был связан; близость к ближневосточным данным, предполагаемая у этрусков и этрусского языка, по отношению к сопоставляемым с ними собственно тирренцам и тирренским диалектам не выявлена. В свете этих новых гипотез вероятно, что начало проникновения неолитических достижений в Европу могло осуществляться отчасти доиндоевропейским населением отдельных ее частей, на которое позднее наслоились индоевропейцы, усвоившие неолитическую технику в полном объеме.

Соединение лингвистических и археологических выводов с генетическими позволяет предположить, что за ранним временем распада индоевропейского праязыка, когда носители отдельных диалектов еще жили по соседству друг от друга (иногда в трудных условиях горной местности, способствовавших разделению и обособлению отдельных групп), и могли происходить морские миграции на короткие расстояния (например, лувийцев из Греции в Малую Азию), следует время более активных перемещений, которым способствует овладение новыми видами транспорта - конями и повозками. Здесь много нового уточнено в последнее время.

В номере журнала Science от 6 марта 2009 г. группа ученых, включающая Алексея Каспарова (Институт истории материальной культуры, СПб), первооткрывателя Ботайской культуры Северного Казахстана Виктора Зайберта (Кокчетавский университете) и ряд других специалистов из научных центров Англии, Франции и США (в частности, Олсен, давно уже исследовавшую Ботайские поселения, Olsen 2006a, b, с), опубликовала статью, излагающую последние результаты их многолетних исследований (Outram et al. 2009). Они приходят к выводу, что лошадь была одомашнена в Северном Казахстане около 3500 г. до н. э. (что на тысячу лет удревняет этот процесс в отличие от хронологии, ранее предполагавшейся в работах Энтони, давно предположившего Ботай как древнее место одомашнивания лошади; для Хвалынска, где известны конские жертвоприношения, иногда предлагается еще более ранняя датировка, тогда как калиброванная радиокарбонная хронология Дереивки, роль лошадей в которой сопоставима с устанавливаемой для Ботая, теперь приближена к бронзовому веку). 
Открытие для культуры Ботая обосновывается совпадением трех результатов разного рода исследований: во-первых, изучение костяков коней из этого ареала уже в названное время указывает на изменение, делавшее животное более приспособленным к использованию человеком. В этом отношении костяки ближе к тем, которые датируются бронзовым веком и отличаются от собственно дикого тарпана (equus ferus ferus), область распространения которого была (до его вымирания) близка к этой же территории. Впрочем, не установлено, можно ли говорить о генетическом отличии ботайских коней от тарпана, поэтому проблема соотнесения с предполагаемым одним (позднее отраженным в Y хромосоме) или разными (предположенными по митохондриальной ДНК) генетическими прототипами одомашненной лошади остается пока открытой. Само по себе различие костной структуры диких тарпанов и ботайских коней может объясняться не только одомашниванием, а другими факторами (на что уже раньше обращала внимание Марша Девин, считавшая, что в Ботае, как и в приблизительно синхронной Дереивке на Днепре, речь идет скорее всего о массовой охоте на лошадей как о главном предмете питания). Поэтому этот аргумент важен не сам по себе, а в соединении с другими.

Во-вторых, авторы статьи (как ранее Энтони и его соавторы - в отличие от М. Девин, с ним полемизировавшей в серии работ, утверждавших дикий характер ботайских коней, по ее мнению служивших для пищи, а не для езды) полагают, что в достаточно большом числе случаев можно предполагать деформацию зубов и десен коней, вызванную удилами (найденные части упряжи делались из костей), см. рис. 1. При отсутствии археологических следов повозок в таком случае предполагается верховая езда.

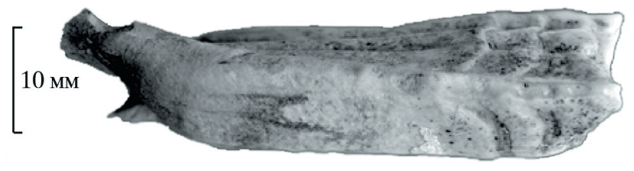

Рис.1. Следы износа на втором предкоренном зубе нижней челюсти лошади из раскопок в Ботае. Среди современных лошадей такие параллельные полоски встречаются только у животных, долгое время проходивших в упряжи.

Возражения, предполагающие патологические причины деформации, отпадают, если явление встречается достаточно часто. Вместе с тем не вполне исключено высказывавшееся ранее той же Девин допущение, что деформация происходила при поимке (с помощью лассо) и первичном объезжании лошадей, которые приручались, но еще не одомашнивались (их после поимки могли держать в стойлах, одно из которых найдено в Ботае). Дополнительный косвенный довод в пользу последнего истолкования основан на допущении, что к одомашненной лошади отношение основано на ласке, а при начальном приручении возможно в большей степени насилие. Но приручение можно рассматривать (по М. Левин) как ранний этап, предшествующий одомашниванию.

В-третьих, удалось установить наличие следов животного жира (кобыльего молока) на (и в) стенках найденных в этом ареале сосудов. Иначе говоря, можно восстановить для этого времени употребление кумыса в пищу. В связи с рассматриваемой ниже возможностью сопоставления с индоевропейским названием лошади стоит заметить, что от этого последнего в древнепрусском языке было образовано название кобыльего молока (вопрос освещается в Словаре прусского языка В. Н. Топорова: Топоров 1975). Принимая, однако, гипотезу о лошади как прежде всего источнике пищи, допустимо считать, что доить можно и прирученную (но еще не одомашненную) кобылу, содержавшуюся в стойле. 
Кроме этих трех основных направлений исследования, суммированных в последней работе Олсен и других, можно также особо отметить обсуждающуюся в ряде ее предшествующих публикаций значимость следов удобрения почвы конским навозом, что было важно для оседлого предземледельческого населения поселений Ботайской культуры. Конский навоз, скорее всего от лошадей, содержавшихся в стойлах или загонах, отражен и в остатках крыш жилищ. Но и этот аргумент совместим с картиной начального этапа приручения лошади.

Культура Ботая была ориентирована на лошадь. Прежде всего при любой интерпретации приведенных фактов остается в силе бесспорный перевес конских костей (около 99\% общего числа найденных в Ботае остатков животных) и вероятность - при единичности примера - массовых конских жертвоприношений в погребальном обряде (напоминающих, как и ряд других черт коневодческой культуры, более позднюю Синташту с евразийскими и индоиранскими параллелями). Картина использования лошадиного мяса в пищу особенно отчетливо выступает в найденных в Ботае ямах для его хранения. См. рис. 2.

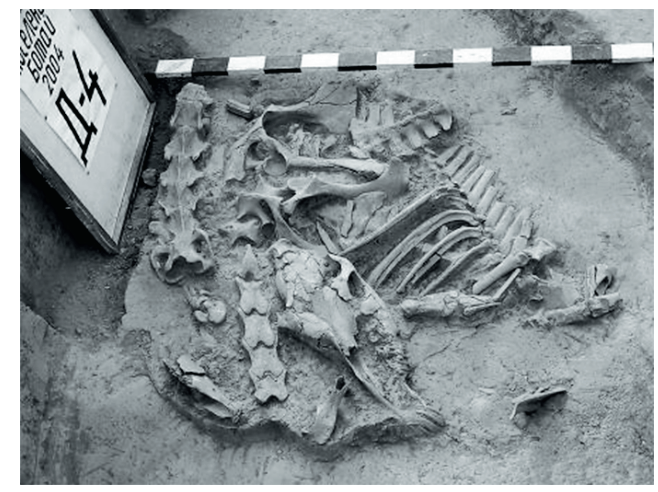

Рис. 2. Ботай. Яма для хранения конины. Остатки костей лошади

Кажется возможным рассматривать два варианта гипотезы относительно роли лошади для культуры Ботая. Сильный вариант изложен в последней статье Олсен и соавторов, предполагающих одомашнивание лошади уже в середине IV тыс. до н. э. Слабый вариант (в духе прежних работ М. Аевин) предполагает для этого времени и места (как возможно и для Дереивки) ранний этап массового приручения лошадей, содержавшихся в стойлах и использовавшихся для доения и в пищу; возможно, что их ловили и объезжали, а потом помещали в загоны и стойла.

Все основные выводы являются отчасти косвенными, но их согласование делает высказываемую гипотезу в двух этих вариантах вероятной. Рассмотрим возможные ее следствия, учитывая, что дальнейшие исследования могут заставить дать предпочтение одному из вариантов.

Ботайская культура необычна тем, что она представляет собой вкрапление оседлых предземледельцев, использовавших коня (для еды и объезжания или - по сильному варианту гипотезы - для езды), в отличие от кочевых народов степи. Это говорит в пользу пришлого характера населения.

Однако судя по предложенным на основании сохранившхся черепов реконструкциям с точки зрения физической антропологии население скорее носило (центрально)азиатский характер (для сопоставления можно привлечь явно европеоидный тип, выявленный на восточнотуркестанских мумиях скорее всего тохарского или иранского происхо- 
ждения; для уточнения путей переселения соответствующего этноса важны как установленные Э. Барбер западные аналогии способам изготовления текстильных изделий, найденных на мумиях, так и проводимые исследования генетического состава населения Алтайского края и Хакасии).

Для попытки отождествления Ботайской культуры с другими этнолингвистическими общностями, по времени к ней близкими, кажется важным состав стада. Жители Ботайских поселений знали только два вида домашних животных - лошадь и собаку. Контраст с составом стада всех известных индоевропейских народов разителен. Свинья могла отсутствовать у некоторых из них по религиозным (и в конечном счете экологическим) причинам. Но другие домашние животные всегда присутствовали. Если предположить, что здесь перед нами группа индоевропейцев, утративших первоначальный состав стада, то возникает труднейшая хронологическая проблема - каков приблизительный возможный срок для такой перемены и в чем ее причины? Общий вид Ботая с большими промежутками между домами совместим с идеей поселения, живущего использованием животных. Но стадо обычного индоевропейского и древнеближневосточного типа отсутствует.

Каковы другие этнолингвистические группы, в это время возможные для Северного Казахстана? Согласно исследованиям А. П. Дульзона по характеру древних гидронимов дотюркское население было по языку енисейским (Дульзон 1962, 1968а, б; 1970). Финноугорские группы и находившиеся с ними в интенсивном контакте иранцы относятся к более поздним обитателям этих и более южных районов. Отмеченное Олсен и другими исследователями сходство типов жилищ с ареалом позднейшей металлоплавительной культуры Синташты-Аркаима не обязательно нужно интерпретировать в духе иранского приурочивания, потому что вопрос и для Синташты пока остается открытым (Григорьев 1999).

Если допустить возможное енисейское население для Ботайской культуры, какие вероятны лингвистические реконструкции? Согласно реконструкции С. А. Старостина, праенисейское *ku?s 'конь,лошадь' (по Вернеру < *ku?t/*ku2s) отражено в кетск. ku2ś, мн.ч. kuśn 'корова', югск. ku2s, мн.ч. kusn 'лошадь'; kujgit 'жеребенок', котск. huš, мн.ч. huс̌an; guš; асc. penguš, pen-kuš 'кобыла'; huš, hiš 'конь', аринск. kus 'конь'; qus; quše 'кобыла'; pinü-kuс̌e 'кобыла', пумпокольск. kut ‘конь, кобыла'; kus ‘конь' [= югск.]. С. А. Старостин полагал,

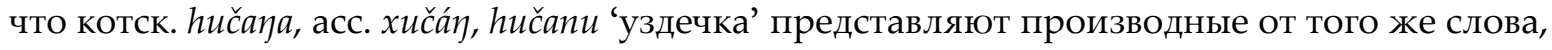
но обращал внимание на особенности кетск. ю.-имбатск. киvаך, мн.ч. ku:ndaךan 'уздечка',

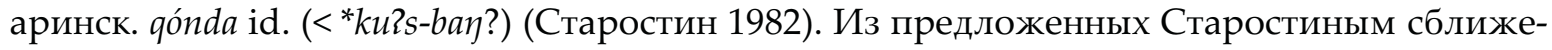
ний в пределах широко понимаемой макросемьи представляется особенно замечательным бурушаски * $g u s$. Для прасино-кавказского он восстанавливал ${ }^{*} g w \bar{a} s \bar{e}>$ сев.- кавказск. * gwāšè ; (сино-тибетск. >) тибет. r-god 'кобыла'. Кажется возможным предположение, что с этим енисейским названием связано восстанавливаемое праиндоевропейское название коня * $\left(h_{1}\right) e \hat{k w o->~ и е р о г л . ~ л у в и и ̆ с к . ~ a s ́ u w a-, ~ с а н с к р и т ~ a s ́ v a-~ ' л о ш а д ь ' ; ~ а в е с т и и ̆ с к . ~ a s p a-, ~ с т .-~}$ литовск. ašva (формы диалектов satəm); тохар. Б уakwe (пример употребления: yakwe pikulne ‘в год лошади' G-Su34.1), тохар. А yuk, лат. еquus, др.-англ. eоh, микенск. греч. i-qo>гомер. їтлоs (ср. Gamkrelidze 1994; Ivanov 2002; Kullanda 2010). Формы диалектов centum совпадают с древнеенисейским названием лошади. Различие касается первого слога, в отношении которого греческий отличается от других лиалектов: след заимствования?21

${ }^{21}$ В связи с этим обстоятельством В. Блажек предположил, вслед за Наартом, что в праенисейском существовало сложное слово *ix-ku’s 'жеребец', рефлекс которого мы видим в коттском ig-huš 'id.', где ig 'самец', huš ‘конь'. Ввиду прозрачной внутренней структуры енисейского слова он считает его вероятным источником индоевропейской формы (Blažek 1998: 26-27). 
Кроме того, в индоевропейском конечный согласный ${ }^{*}$-s интерпретирован как флексия в результате переосмысления и переразложения заимствованной основы в пределах праиндоевропейской морфологии. Старостин считал возможным наличие праенисейских заимствований в индоевропейском (часть их была впервые открыта Дульзоном). Эту возможность он не раз в разговорах обсуждал по поводу названия «слезы» (из енисейского «вода + глаза», типологически вероятного).

Предполагается, что миграции индоевропейцев осуществлялись в основном посредством колесных повозок, в которые впрягались лошади; в военных предприятиях главную роль играли боевые колесницы. Соответственно история этих транспортных средств и связанные с ними вопросы, такие, как одомашнивание лошади, заняли внимание многих ученых. Хотя общего мнения достичь не удалось, сформулированы две противоположные точки зрения, выбор между которыми в дальнейшем определит направление исследований. Первая из них связана главным образом с работами Дэвида Энтони (Anthony 2007). Он примыкает к тому течению, которое вслед за М.Гимбутас (в свою очередь развивавшей точку зрения, задолго до того обосновывавшуюся Шрадером) искало колыбель индоевропейцев в Северном Причерноморье. Энтони свои усилия сначала сосредоточил на исследовании многочисленных остатков коней в Дереивке на Днепре, где он и следовавшие за ним ученые видели следы древнего центра коневодства. В работе, вызвавшей бурную полемику, Энтони пробовал показать, что на зубах одного коня из Дереивки можно видеть следы повреждений, нанесенных человеком. Позднее, после открытия еще большего количества костных остатков лошадей в Ботае в Казахстане, Энтони склонился к точке зрения, согласно которой древнейшую область одомашнивания лошади и ранней верховой езды нужно искать в Северном Казахстане, где на зубах многих коней ему видятся аналогичные следы грубой дрессировки. Развитие этой точки зрения и осуществлено в обсуждаемых новейших трудах. Отвергая выводы Энтони, Марша Девин считает Волжско-Казахстанские степи в IV и III тыс. до н. э. областями охоты за лошадьми, но не их одомашнивания (Levine 2003). Девин участвует в большой коллективной работе с генетиками по выявлению следов одомашнивания посредством методов молекулярной биологии (Jansen et al. 2002). Установлено, что лошадь была одомашнена несколько раз в разных местах. В этом, в частности, можно видеть биологическое соответствие лингвистическому выводу о наличии не менее двух древних евразийских названий лошади: одного, общего у индоевропейского * $\left(h_{1}\right) e \hat{k} w o-s$ с енисейским *-qu2s и заимствованного с изменением палатального в семитский и вероятно в северокавказский (см. выше), и другого, заимствованного из сино-тибетского ${ }^{*} k u m r a n g 22$ в алтайские (яп. *uma и монг. *mórin) и в некоторые индоевропейские (англ. mare ${ }^{23}$ с соответствиями в других германских языках и в кельтском) языки. Даты многократного одомашнивания лежат в интервале между началом неолитической революции (9000 лет до н. э.) и тем периодом около 2000 лет до н. э., когда о ритуальном захоронении одомашненной лошади вместе с колесницей говорит находка в культуре Синташты. Все исследователи проблемы, включая и представителей противоположных взглядов на начальный период одомашнивания, сходятся на том, что начиная с рубежа III-II тысячелетий

22 Жангжунг hrang; паттани (манчати) Hrang; лахули rhang; рангкас rhang; канаури rang; дармия, чаудангси, бьянгси rang; др.-тиб. (дунхуанские рукописи) rmang; пралоло-бирманск. *mrang (> mraang, лаху i-mu); цзинпо (диалект хикаури) guumrang (Matisoff 2004).

${ }^{23}$ Наличие в германских языках слова, соответствующего восточно-азиатским названиям лошади, было одним из лингвистических открытий Лейбница. Форма, близкая к исходной сино-тибетской, могла лечь в основу славянского заимствования, представленного в др.-русск. комонь > конь. 
одомашненный конь в сочетании с колесной повозкой и колесницей, в которые он впрягается, с удивительной быстротой распространяется по всей Евразии от Европы до Китая и проникает в Египет. Для начала этого поразительного по быстроте и всеобщности процесса в научной литературе последних лет отмечаются два свидетельства: изображения колесниц на печатях из староассирийских документов в Канише, что можно сопоставить с ролью лошади в начинающихся несколькими веками позже древнехеттских и лувийских текстах, в том числе и в связи с культом обсуждавшегося выше божества Перва, изображаемого на лошади, и захоронение в культуре Синташты. Поскольку последняя часто (но не обязательно) связывается с индоиранцами, а в Канише (Gökçеk 2006) использование колесниц (вероятно в сочетании с конями, хотя эти последние реконструируются только по косвенным данным) можно соотнести с местным населением, говорившим по-несийски, в обоих случаях допустимо предполагать, что ранние свидетельства появления одомашненных лошадей вместе с колесницами встречаются там, где есть следы индоевропейцев. Для более полного изучения этой проблемы большое значение могут иметь недавние открытия руководимой Дж. Буччеллати археологической экспедиции, исследующей древнехурритскую столицу Уркеш (Мозан) в северо-восточной Сирии неподалеку от турецкой и иракской границ. Во дворце, датируемом XXII в. до н. э., найдено очень значительное число миниатюрных фигурок лошадей или зоологически близких типов эквидов. По оценке специалистов изображения относятся к одомашненной лошади. По хронологии они близки к печатям из Каниша. Особый интерес представляет относящаяся к несколько более раннему времени скульптура головы лошади. Такие изображения встречаются в нескольких культурных центрах второй половины III и начала II тыс. до н. э. К ним относится в Маргиане бронзовое навершие в виде головы лошади в Гонур-депе. Кажется возможным соотносить такого рода изображения с уже происшедшим одомашниванием. В Уркеше можно думать о его времени, близком к середине III тыс. до н. э. Данные о коневодстве в Уркеше представляется целесообразным сопоставить с фактами, ставшими известными о Маргиане. В Маргиане, где одомашнивание для рубежа III и II тыс. до н. э. доказывается кроме упомянутого навершия обрядовым захоронением жеребенка и находкой рожков, использовавшихся при тренинге лощадей, предполагается ранняя дата начала одомашнивания. Хотя (в отличие от Митанни середины следующего тысячелетия) в Уркеше (как и в письменных древнехурритских текстах) достоверных данных о симбиозе хурритского с арийским диалектом в сфере коневодческой лексики пока не обнаружено, о контакте хурритов с коневодами, говорившими на одном из диалектов satam, возможно свидетельствует само предполагаемое хурритское название лошади еššе, заимствованное из такого диалекта (Ivanov 2002; Иванов 2004; ср., однако, гипотезу А. Милитарева и Г. Старостина, Старостин 2007: 879, 4.а.1). Таким образом перечисление ранних центров коневодства, связываемых с индоевропейцами (предположительно преимущественно индоиранцами-ариями), можно построить в таком приблизительном хронологическом порядке: древнехурритская столица Уркеш, староассирийский Каниш с анатолийским (древнехеттским и лувийским) населением, для которого двумя веками позже достоверно использование боевых колесниц вместе с конями, Синташта (где есть основания предполагать иранский слой населения), Маргиана (Гонур), для которой предположен также древнеарийский (иранский) пласт населения (Иванов 2004). Несколькими веками раньше возможное свидетельство индоевропейского культа лошади можно предположить в Эбле. Среди вызвавших интерес образцов эблаитских писем есть одно, упоминающее князя соседней области, носившего имя Zizi; возможно, оно образовано от того названия коня, которое из индоевропейского диалекта satəm было заимствовано в семитские языки и в шумерский. Аич- 
ные имена, включавшие такое имя лошади, известны в разных древних индоевропейских традициях.

Если нанести на карту так или иначе связанные с индоевропейцами места, где для этой ранней поры отмечаются прямые или косвенные следы одомашнивания лошади, ее использования в сочетании с колесницей, ее культа и ее (скульптурных) изображений, то можно увидеть, что наиболее ранние из только что перечисленных (Эбла, Уркеш, Каниш) группируются вокруг сирийско-малоазийско-анатолийского ареала. Дошадь в этой части Евразии не обязательно должна была быть одомашнена (только) индоевропейцами. По лингвистическим данным на эту роль могли бы претендовать, например, и носители распространенных на севере Средней Азии енисейских диалектов, откуда древнее название могло проникнуть в праиндоевропейский. Но откуда бы ни пришло это новшество в область Ботая-Хвалынска-Дереивки, индоевропейцы быстро и успешно его внедрили (быть может, усовершенствовав выведение определенных пород коней и способов их тренировки, чем славились месопотамские арийцы из Митанни). Складывается представление, что после освоения лошадей и колесных повозок и колесниц на рубеже III и II тыс. до н. э. некоторые группы индоевропейцев стали распространяться с большой скоростью из предполагаемой нами прародины на восток: на севере в Синташте-Аркаиме, на юге - в Маргиане. Но остается вопрос: а как передвигались индоевропейцы до этого? Достоверных данных об использовании индоевропейцами одомашненных лошадей до середины III тысячелетия пока нет. Предположение о том, что основные ранние миграции индоевропейцев осушествлялись с помощью еще примитивных колесных повозок, в которые впрягались быки, не кажется правдоподобным. Представляется вероятным, что надежных сухопутных средств быстрого передвижения на большие расстояния у индоевропейцев в период, близкий к распаду их праязыка, еше не было, но широко применялся водный транспорт (в частности, в причерноморском «циркумпонтийском» ареале).

Этому выводу не противоречат и данные, касающиеся истории колесных повозок. Наиболее древние из них, известные в ямной культуре Евразии IV тыс. до н. э., еше не могли быть достаточно мобильными для предполагаемых больших миграций. Как и по отношению к лошади, за периодом подготовительных проб, которые в III тыс. до н. э. осуществлялись в основном в пределах Ближнего Востока, окончательный успех был достигнут только к началу II тыс. до н. э., после чего начинается триумфальное шествие боевой коле сницы и ее мирного аналога по Евразии.

К периоду, когда индоевропейцы уже начали использовать колесные повозки и лошадь для запряжки и для наездничества, относятся перемещения кочевников на большие расстояния. Представляется существенным разграничение этой и предшествующей эпох, но вместе с тем между ними не прерывалась преемственность. У хеттов, которые скорее всего переместились к центру и на север Анатолии в более позднее время, к этому периоду уже были колесные повозки, запряженные конями. Но их более раннее расселение по Малой Азии могло произойти еще в период сравнительно медленного движения по суше, отчасти одновременного с морскими переселениями лувийцев. Реконструкция трехтысячелетнего периода этой ранней дописьменной предыстории индоевропейцев представляет задачу комплекса нескольких наук, сотрудничество которых предполагает строгий контроль возможности синхронизации их данных и точного соблюдения временных границ. Предстоящее обсуждение призвано пролить свет на этот вопрос.

Возвращаясь к оценке в свете известных теперь данных гипотезы, выдвинутой нами 40 лет назад, можно признать, что приурочение прародины индоевропейцев к Месопо- 
тамии или близкой к ней части Древнего Ближнего Востока (возможно, более южной, чем нам представлялось) кажется весьма вероятным (особенно благодаря открытию большого числа древних заимствований). Но последние археологические открытия, как исследования Гонур-Депе экспедицией В. И. Сарианиди, и дальнейшее изучение ареала Синташты-Аркаима, могут внести существенные уточнения в предположенные нами ранее пути позднейших миграций времени после овладения колесными повозками и одомашненными лошадьми. В частности, более отчетливо выявляется позднейшая роль Маргианско-Бактрийского комплекса (BMAС) и Синташты-Аркаима, о которых мы располагали только ранними публикациями времени подготовки к печати нашей книги.

\section{Питература}

ГАМКРЕДИДЗЕ Т. В., ИВАНОВ Вяч. Вс. 1980. Древняя Передняя Азия и индоевропейская проблема. Временные и ареальные характеристики общеиндоевропейского языка по лингвистическим и культурно- историческим данным. - Вестник древней истории, № 3, стр. 3-27.

ГАМКРЕДИДЗЕ Т. В., ИВАНОВ Вяч. Вс. 1981. Миграции племен-носителей индоевропейских диалектов с первоначальной территории расселения на Ближнем Востоке в исторические места их расселения в Евразии. - Вестник древней истории, № 2, стр. 11-13.

ГАМКРЕДИДЗЕ Т. В., ИВАНОВ Вяч. Вс. 1984. Индоевропейский язык и индоевропейцы. 2 т. Тбилиси.

ГАМКРЕАИДЗЕ Т. В., ИВАНОВ Вяч. Вс. 1989. Первые индоевропейцы на арене истории: прототохары в Передней Азии. - Вестник древней истории. № 1.

Григорьев С. А. 1999. Аревние индоевропейцъь. Опыт исторической реконструкциии. Челябинск, 1999.

ДульзОн А. П. 1962. Былое расселения кетов, по данным топонимики. - Вопросы географии 58: Географические названия. - М., с. 50-84.

ДульзОН А. П. 1968а. О древней центральноазиатской языковой общности. - Вопросы русского языка и его говоров. Томск.

ДульзОН А. П. 1968б. Кетский язык. Томск: ТГУ.

ДульзОн А. П. 1970. Этнически дифференцирующие топонимы Сибири и Дальнего Востока. - Языки и топонимия Сибири. Новосибирск.

ИвАНОв Вяч. Вс. 2004. Двадцать лет спустя. О доводах в пользу расселения носителей индоевропейских языков из древнего Ближнего Востока. - У истоков цъивиизации: Сб. к 75-летию В. И. Сарианиди. М., с. $41-$ 67.

Иванов Вяч. Вс. 2007. Труды по этимологии индоевропейских и древнепереднеазиатских языков. Т. 1: Индоевропейские корни в хеттском языке и особенности их структуры. М.: Языки славянской культуры.

ИвАнОв Вяч. Вс. 2008. Анатолийские личные имена и слова в староассирийских текстах XX-XVIII вв. до н. э. - древнейшие свидетельства об индоевропейских языках. - Вопросы языкознания, № 4.

ИвАНОВ Вяч. Вс. 2010. Древнейший индоевропейский письменный текст: надпись Анитты, царя Куссара (XVIII в. до н. э.) в истории хеттологии. - ИвАНОВ Вяч. Вс. Избранные труды по семиотике и истории культуры. Т. 7, кн. 2. М.: Знак, с. 9-95.

ИвАНОв Вяч. Вс. 2011. К историческому объяснению форм этрусского языка. - Laurea Lorae. Сб. Памяти 1. Степановой. СПб, с. 68-103.

ИвАнОв Вяч. Вс., ТОПОРОв В. Н. 1974. Исследования в области славянских древностей. М.

Климов Г. А. 1994. Аревнейшие индоевропеизмы картвельских языков. М.

Климов Г. А. 1994а. Картвельское иsхо- «бык жертвенный» - индоевропейское *uks-on-. - Этимология 1990-1993. М. Наука, с. 154-158.

КулААНДА С. В. 2008. Лошадь в праиндоевропейском. - Orientalia et Classica XIX: Acnекть компаративистики 3. Москва, с. 669-678.

МЕРПЕРт Н. Я. 1988. Об этнокультурной ситуации IV - III тысячелетий до н. э. в циркумпонтийской зоне. Древний Восток. Этнокультурные связи. М.: Наука, гл. ред. вост. лит-ры, стр. 7-36.

МэллОри Дж. П. 1997. Индоевропейские прародины. - Вестник древней истории, № 4.

Порциг, В. 1960. Членение индоевропейской языковой области. Пер. с нем. М. [нем. изд.: 1954]. 
САФРОНОв В. А. 1989. Индоевропейские прародины. Горький.

СтАРОстин С. А. 1982. Праенисейская реконструкция внешние связи енисейских языков. - Кетский сборник. А., с. $144-235$.

СТАРОСТИН С. А. 2007. Труды по языкознанию. М.: Языки славянской культуры.

ТОПОРОв В. Н. 1975. Прусский язык. Словарь. Т. 1. М.: Наука.

ЯнковскАЯ, 1968. Клинописнье тексты из Кюль-Тепе в собраниях СССР. Письма и документы торгового объединения в Малой Азии ХІХ в. до н.э. Автографические копии, транскрипция, пер., вводн. ст., коммент. и глоссарий Н. Б. Янковской (= Памятники Востока XIV). М.: Наука, Гл. ред. вост. лит-ры.

AnTHONY D. 2007. The Horse, the Wheel, and Language. Princeton University Press.

BLAŽEK V. 1998. Is Indo-European ${ }^{*} H_{1} e \hat{k} w o$ - 'horse' really of Indo-European origin? - Studia Indogermanica Lodziensia 2, pp. 23-32.

Bouckaert R., Lemey P., Dunn M., Greenhill S. J., Alekseyenko A. V., Drummond A. J., Gray R. D., Suchard A., AtKINSON Q. D. 2012. Mapping the Origins and Expansion of the Indo-European Language Family. - Science, Vol. 337, No. 6097, pp. 957-960.

CARruba O. 1995. L'arrivo dei greci, le migrazioni indoeurpee e il 'ritorno' degli Eraclidi. - Athenaeum 85, pp. 544.

Crowell B. L. 2001. The Development of Dagan: A Sketch. - Journal of Ancient Near Eastern Religions 1, pp. 3283.

DercKsen J. G. 2007. On Anatolian loanwords in Akkadian texts from Kültepe. - Zeitschrift für Assyriologie und vorderasiatische Archäologie, Bd. 97: 26-46.

Dolgopolsky A. 1988. The Indo-European homeland and lexical contacts of Proto-Indo-European with other languages. - Mediterranean Language Review 3: 7-31.

ERHART A. 1995. Archaisch oder konservativ? Das Anatolische und das Baltische. - Kuryłowicz Memorial volume. Part 2. Ed. W. Smoczyński. Linguistica Baltica IV. Kraków.

FELIU L. 2003. The God Dagan in Bronze Age Syria. Leiden.

FRAYNE D. R. 1992. Indo-Europeans and Sumerians: Linguistic Contacts. - Canadian Society for Mesopotamian Studies Bulletin, 25.

GAMKRELIDZE Th. V. 1970. Anatolian languages and the problem of Indo-European migration to Asia Minor. Studies in General and Oriental Linguistics. Tokyo.

GAMKRELIDZE Th. V. 1988. Ex Oriente Lux. On the problem of an Asiatic homeland of the Proto-Indo-Europeans. - Languages and Cultures. Studies in Honor of Edgar C. Polomé, ed. By Mohammad Ali Jazayery and Werner Winter. Berlin-New York-Amsterdam: Mouton de Gruyter, pp. 161-167.

GAMKRELIDZE Th. V. 1990. Tipología lingüística y consonantismo indoeuropeo. - Studia Indogermanica et Palaeohispanica in Honorem A. Tovar et L. Michelena, editado por F. Villar. Salamanca: Ediciones Universidad de Salamanca / Servicio Editorial de la Universidad del País Vasco, pp. 225- 233.

GAMKRELIDZE Th. V. 1994. PIE horse and cart in the light of the hypothesis of Asiatic homeland of the IndoEuropean. - B. HÄNSEL \& S. ZIMMER (eds.). Die Indogermanen und das Pferd. Budapest: Archaeolingua, pp. $37-42$.

GAMKRELIDZE Th. V. 1995. The root structure and apophony in Kartvelian (South Caucasian) and Indo-European. - Kuryłowicz Memorial Volume. Part 1. Kraków: Universitas, pp. 81-91.

GAMKRELIDZE Th. V. 2006. Selected Writings. Innsbruker Beiträge zur Sprachwissenschaft, Bd. 122. Innsbruck.

GAMkrelidze Th. V., Ivanov, V. V. 1990. The Early History of Indo-European Languages. - Scientific American, vol. 262, No. 3, March.

GAMKRELIDZE, TH. V., IVANov Vyach. Vs. 1995. Indo-European and Indo-Europeans. Vol. 1-2. Berlin-New York: Mouton-de Gruyter.

GAMKRElidze, TH. V., IVAnOV Vyach. Vs. 2006. Les premiers Indo-Européens de l'histoire. - Gamkrelidze 2006, pp. $122-153$.

GÖKÇEK L. G. 2006. The Use of Wagons (eriqqum) in Ancient Anatolia According to Texts from Kültepe. Zeitschrift für Assyriologie und vorderasiatische Archäologie, Bd. 96, 2.

GoEdebUURE P. 2007. The original function of the Hittite sentence particle -kan: topic reinforcer or marker of spatial relations? Review article of Jacqueline Boley's Dynamics of Transformation in Hittite (Innsbruck 2000). - Bibliotheca Orientalis 64/1-2, pp. 31-63. 
GRAY R. D., ATKINSON Q. D. 2003. Language-tree divergence times support the Anatolian theory of Indo-European origin. - Nature, vol. 426, 27 November, pp. 435-438.

GUSMANI R. 1968. Il lessico ittito. Napoli.

HiLl J. E. 2004. The Peoples of the West from the Weilue 魏略 by Yu Huan 魚䅈. A Third Century Chinese Account Composed between 239 and 265 CE Quoted in zhuan 30 of the Sanguozhi Published in 429 CE. Draft English translation September by John E. Hill. September, 2004. - Available at:

http://depts.washington.edu/silkroad/texts/weilue/weilue.html

IVANOV Vyach. V. 2001. Southern Anatolian and Northern Anatolian as separate Indo-European Dialects and Anatolian as a late linguistic Zone. - Greater Anatolia and the Indo-Hittite Language Family. Papers presented at a Colloqium hosted by the University of Richmond, March 18-19, 2000 (JIES Monograph Series 38.) Washington D.C.: The Institute for the Study of Man, pp.131-183.

IVANov Vyach. V. 2002 Comparative Notes on Hurro-Urartian, Northern Caucasian and Indo-European. - Languages and their Speakers in Ancient Eurasia. Dedicated to Prof. A. Dolgopolsky on his 70 th birthday. Ed. V. Shevoroshkin and P. Sidwell. Association for the History of Language. Monograph series 1. AHL Studies in the Science and History of Language. Vol. 5. Canberra,. P. 143-234.

IvANOv Vyach. V. 2007. The Indo-European Homeland in the Near East: New Evidence. - Bulletin of the Georgian Academy of Sciences 1.

IVANOV Vyach. V. 2007a. Les noms propres et les mots anatoliens dans les texts paléo-assyriens de XXème - XVIII ${ }^{\mathrm{e}}$ siècles avant J.C. - les témoignages les plus anûciens des langues indo-européennes. - Societas Anatolica, Bulletin, no 1.

IVANOV Vyach. V. 2008, Archaic Indo-European Anatolian Names and Words in Old Assyrian Documents from Asia Minor (20 th $-18^{\text {th }}$ Centuries BC). - Proceedings of the $19^{\text {th }}$ Annual UCLA Indo-European Conference. Washington, DC, pp. 219-237..

Jansen T., Forster P., Levine M. A., Oelke H., Hurles M., Renfrew C., Weber J., Olek O. 2002. Mitochondrial DNA and the origins of the domestic horse. - Proceedings of the National Academy of Sciences USA 99 (16), pp. 10905-10910.

Keller A., Graefen A., Ball M., Matzas M., Boisguerin V., Maixner F., Leidinger P., Backes C., Khairat R., Forster M., Stade B., Franke A., Mayer J., Spangler J., Mclaughlin S., Shah M., Lee C., Harkins T. T., Sartori A., Moreno-Estrada A., Henn B., Sikora M., Semino O., Chiaroni J., Rootsi S., Myres N. M., Cabrera V. M., Underhill P. A., Bustamante C. D., Vigl E. E., Samadelli M., Cipollini HaAs G., Katus H., O’Connor B. D., Carlson M. R. J., Meder B., Blin N., Meese E., Pusch E. \& Zink A. 2012. New insights into the Tyrolean Iceman's origin and phenotype as inferred by whole-genome sequencing. - Nature Communication, 3, Article number: 698 doi:10.1038/ncomms1701.

KLIMOV G. A. 1998. Etymological Dictionary of the Kartvelian Languages. Berlin/New York: Mouton de Gruyter.

KRYSZAT G. 2006. Herrscher, Herrschaft und Kulttradition in Anatolien nach den Quellen aus den altassyrischen Handelskolonien. Teil 2. Götter, Priester und Feste Altanatoliens. - Altorientalische Forschungen 33: $102-124$.

Kullanda S. 2010. The name of the horse in Proto-Indo-European. - Horses, Chariots and Chariot's Drivers of Eurasian Steppes. Yekaterinburg-Samara-Donetsk, pp. 85-88.

LEVInE M. 2003. The exploration of horses at Botai, Kazakhstan. - C. REnFreW \& K. BoyLE (eds.). Prehistoric Steppe Adaptation and the Horse. McDonald Institute Monographs, Cambridge, pp. 83-104.

LIU Xinru. 2001. Migration and Settlement of the Yuezhi-Kushan: Interaction and Interdependence of Nomadic and Sedentary Societies. - Journal of World History, Volume 12, Number 2, Fall, pp. 261 -292.

Mallory J. P., MaIr V. H. 2000. The Tarim Mummies: Ancient China and the Mystery of the Earliest Peoples from the West. New York: Thames and Hudson.

MATISOFF J. 2004. The interest of Zhangzhung for comparative Tibeto-Burman. Available at: stedt.berkeley.edu/pdf/JAM/Zhangzhung-reformat.wp3.pdf

Mendizabal I., Lao O., Marigorta U. M., Wollstein A, Gusmão L., FeraK V., IoAna M., Jordanova A., Kaneva R., Kouvatsi A., Kučinskas V., Makukh H., Metspalu A., Netea M. G., Pablo R. De, Pamjav H., Radojkovic H., Rolleston S. J. H., Sertic J., Macek M., Comas D., Kayser M. 2012. Reconstructing the Population History of European Romani from Genome-wide Data. - Current Biology, 6 December.

OlsEN S. L. 2006a. Early horse domestication on the Eurasian steppe. - M. A. ZEDER, D. G. BRADLEY, E. EMSHWILler, B. D. SMith. Documenting Domestication: New Genetic and Archaeological Paradigms. Berkeley: University of California Press: 245-269. 
Olsen S. L. 2006b. Introduction. - S. L. Olsen, S. Grant, A. M. ChoYKe, L. Bartosiewicz (eds.). Horses and Humans: The Evolution of Human-Equine Relationships. Oxford: BAR International Series 1560: 1-10.

Olsen, S. L. 2006c. Early horse domestication: Weighing the evidence. - S. L. Olsen, S. GrANT, A. M. CHOYKE, L. BARTOSIEWICZ (eds.). Horses and Humans: The Evolution of Human-Equine Relationships. Oxford: BAR International Series 1560: 81-113.

Outram Alan K., Natalie A. Stear, Robin Bendrey, Sandra Olsen, Alexei Kasparov, Victor Zaibert, Nick Thorpe, Richard P. Evershed. 2009. The Earliest Horse Harnessing and Milking. - Science. Vol. 323. No. 5919, March, pp. 1332-1335.

PAgEL M., ATKINSON Q. D. \& MEADE A. 2007. Frequency of word-use predicts rates of lexical evolution throughout Indo-European history. - Nature, vol. 449, 11 October, pp. 717-721.

POMPONIO F. et XELla P. 1997. Les dieux d'Ebla. Étude analytique des divinités éblaïtes à l'époque des archives royales du IIIe millénaire. Alter Orient und Altes Testament. Bd. 245. Münster: Ugarit-Verlag.

PuHVEL J. 1982. Balto-Anatolian Isoglosses. - Investigationes philological et comparative. Gedenkschrift für H. Kronasser. Ed. E. Neu. Wiesbaden.

PuHvel J. 1999. Names and Numbers of the Pleiads. - Semitic Studies in Honor of W. Leslau. Wiesbaden: Otto Harrassowitz, pp. 1243-1247.

RENFREW C. 1987. Archaeology and Language: The Puzzle of Indo-European Origins. London.

RENFrEW C. 2002. The Indo-European Problem and the Exploitation of the Eurasian Steppes: Questions of Time Depth. - K. Jones-Bley, D. G. ZdAnovich (eds.). Complex Societies of Central Eurasia from the $3^{\text {rd }}$ to the $1^{\text {st }}$ Millennium BC, Vol. 1. Washington, D. C.: Inst. for the Study of Man, pp. 3-20.

Renfroe F. 1992. Arabic-Ugaritic Lexical Studies, Münster, pp. 91-94.

Sikora M., Carpenter M., Moreno-Estrada A., Henn B. M., Underhill P. A, Zara I., Pitzalis M., Sidore C., Reinier F., Marcelli M., Angius A., Jones C., Harkins T. T., Keller A., Zink A., Abecasis G., SAnNA S., Cucca F., Bustamante C. D. 2012. On the Sardinian ancestry of the Tyrolean Iceman. - Presented at the $62^{\text {nd }}$ Annual Meeting of The American Society of Human Genetics, November 7 San Francisco, California.

SINGER I. 2000. Semitic dagān and Indo-European ${ }^{*} d^{h} e^{h}{ }^{\text {hh }}$ om: Related Words? - The Asia Minor Connexion, edited by Yoël L. Arbeitman, Louvain, pp. 221-232.

THOMAs W. 1985. Die Erforschung des Tocharischen (1960-1984), Stuttgart.

TISCHLER J. 1995. Die kappadokische Texte als älteste Quelle indogermanischen Sprachgutes. - O. CARRUBA, M. GIORGIERI, C. MORA (eds.). Atti del II congressso internazionale di Hittitologia. Pavie, p. 359-368.

WALS $2005=$ World Atlas of Linguistic Structures. Ed. B. COMRIE a.o. Berlin.

WHITTAKER Gordon. 1998. Traces of an early Indo-European language in Southern Mesopotamia. - Göttinger Beiträge zur Sprachwissenschaft 1, pp. 111-147.

WHITTAKER Gordon. 2004. Word formation in Euphratic. - Indo-European Word Formation. Proceedings of the Conference held at the University of Copenhagen. Copenhagen: Museum Tusculanum Press, pp. 381-423.

ZERJAL T. et al. 1999. The use of Y-chromosomal DNA variation to investigate population history: recent male spread in Asia and Europe. - S. S. PAPIHA, R. DEKA, R. CHAKRABORTY (eds.). Genomic Diversity: Applications in Human Population Genetics, pp. 91-101

Tamaz GAMKRELIDZE, Vyach. Vs. IVANOV. Indo-European homeland and migrations: half a century of studies and discussions.

The problem of the initial place from which the original Indo- European dialects spread over Eurasia has been studied by several generations of scholars. Few alternative points of view have been proposed: first an area near the North Sea (in the works of some scholars of the border of the $19^{\text {th }}$ and $20^{\text {th }}$ centuries), then the North coast of the Black Sea (an old idea of Schrader revived by Maria Gimbutas and her followers) or an area closer to the more eastern (Volga-Ural) parts of Central Eurasia. 40 years ago we suggested first in a talk at a conference, then in a series of articles and in a resulting book (published in Russian in 1984) that the Northern part of the Near East (an area close to North-East Syria and North Mesopotamia) may be considered as a possible candidate for the Indo-European homeland; similar suggestions were made by C. Renfrew and other scholars in their later works. Recent research on these topics has brought up additional evidence that seems to prove the Near Eastern hypothesis for the time 
that had immediately preceded the dispersal of the Indo-European protolanguage. Indirect evidence on the early presence of Indo-Europeans in the areas close to the Near East can be found in the traces of ancient contacts between linguistic families in this part of Eurasia. Such contacts between Proto-IndoEuropean and Proto-Kartvelian have been suggested in the work of T. Gamkrelidze and G. Mach'avariani more than 60 years ago. The following studies have established a number of important loanwords from Proto-Indo-European in Proto-Kartvelian. Particularly interesting discoveries in this field were made by the late G. A. Klimov. He has found many new common elements of the two families in addition to a relatively long list in our joint work. The main difficulty in interpreting the results of his investigations is connected to the problem of a possible common Nostratic origin both of Proto-IndoEuropean and of Proto-Kartvelian. If these two linguistic families were originally cognate, then some part of the correspondences found by Klimov and other scholars might be traced back to the early period of Proto-Nostratic (more than 10000 years ago). Only those words that were not inherited from this ancient time are important as a proof of the later presence of Proto-Indo-European in the area close to the Proto-Kartvelian (to the southwest of the Transcaucasian area in which the latter spread in the historic time). In our book, published in 1984, we suggested some common terms shared by these languages, explaining them as possible traces of later Indo-European (probably Indo-Iranian) migrations through the Caucasus.

The study of this problem has been enriched through the recent research on Proto-North Caucasian. S. L. Nikolaev and S. A. Starostin have compiled a large etymological dictionary of this family, furthering the comparative studies started by Prince N. S. Trubetzkoy. Starostin has gathered a large collection of the terms of material culture common to North Caucasian and Indo-European. They include many names of domestic animals and animal body parts or products of cattle-breeding, plants and implements. In a special work on this subject Starostin suggested that all these terms were borrowed in the area of the Near East to the South of Transcaucasia in the early $5^{\text {th }} \mathrm{mil}$. BC. Although we still use the traditional term "North Caucasian", it is not geographically correct even if applied to such living languages as Abkhaz and to the extinct Ubykh (spoken originally at the southern part of the South-West Transcaucasian area). Since both Hurro-Urartian and Hattic (two ancient dialects of this linguistic group) were spoken in the regions to the South of Transcaucasia already in the $3^{\text {rd }} \mathrm{mil}$. BC, it becomes possible to pinpoint the homeland of the whole family (which at that time was not North Caucasian) in the same area close to the supposed Proto-Indo-European and Proto-Kartvelian homelands.

The fricative $\check{s}$ in the Hurrian name for 'horse', ešša, and an affricate * $\check{c}(>\check{s})$ in the forms of the other North Caucasian dialects correspond to the Proto-Indo-European palatal stop * $k$ ' that has become an affricate $*^{*}$ and then a fricative $\check{s} / s$ in the Indo-European languages of the satam type. Similar changes are present in the other borrowings discussed by Starostin. He supposed that the common words discovered by him were mostly borrowed from Proto-North Caucasian (or from a dialect of it) into ProtoIndo-European. The opposite direction of borrowing from an Indo-European dialect of a satam type can be suggested due to the typologically valid laws of sound change. But no matter which direction of the borrowing should be chosen, the existence of these loanwords is beyond doubt. They clearly point to the location of the Indo-European homeland.

In our monograph we suggested that several words shared by Semitic and Indo-European (such as the ancient term for 'wine', Hittite wiyana-) can be considered Proto-Indo-European borrowings (as distinct from the rest of the most ancient old Semitic or Afro-Asiatic loanwords in Proto-Indo-European). S. A. Starostin suggested that a large number of (mainly West) Semitic words that did not have correspondences in the other Afro-Asiatic languages had been borrowed from Proto-Indo-European. He came to the conclusion: "the original Indo-European (Indo-Hittite) homeland was somewhere to the North of the Fertile Crescent from where the descendents of Indo-Hittites could have moved in two directions (starting with early $5^{\text {th }}$ millennium BC) to the South where they came into the contact with the Semites, and indeed could have driven a part of them further to the South, and to the North (NorthEast) whence they ultimately spread both to Europe and to India". The interference of the early dialects of Proto-Indo-European, Proto-Semitic and Proto-Kartvelian to which the early Proto-"North" Caucasian can be added might have led to the formation of a sort of linguistic zone (Sprachbund) that not only shared many words pertaining to a new farming economy, but also had several phonological and grammatical features in common. 
After we had published our hypothesis on the Near Eastern homeland of the Indo-Europeans, several scholars asked us why, at a time when writing had already been invented, there were no written documents testifying to the presence of Indo-Europeans in these areas. It seems that now there are several possible answers to the question. The great specialist on Iranian, W. B. Henning, who had worked for many years on the problem of the name of Tocharians, suggested in a posthumous article that their early ancestors were Gutians who had invaded Mesopotamia in ca. 2350-2200 BC. In an article written after we had already published our book, we have developed Henning's idea (based mainly on the etymological links of Near Eastern Guti and Tukri and Central Asian names of corresponding IndoEuropean Kuchean and Tocharian ethnic groups), also paying attention to the possible explanation of some names of Gutian kings preserved in Sumerian texts. Recently it has been suggested that an unknown "Pre-Sumerian" language, reconstructed on the basis of the phonetic values of many cuneiform signs, was an archaic "Euphratic" Indo-European dialect spoken in Southern Mesopotamia in the second half of the $4^{\text {th }}$ mil. BC. According to this hypothesis, the phonetic values of approximately one hundred of the early signs that are different from the Sumerian ones go back to the Euphratic words. A large number of Anatolian personal names (of a very archaic Indo-European type) have been found in the Old Assyrian texts from trade colonies in Asia Minor. The continuation of the excavations in Kanish that have yielded more than 23000 cuneiform tablets has made it possible to discover in them many Anatolian Indo-European names and loanwords. The Old Assyrian documents in Kanish are encountered in the archaeological levels II and Ib dated by the first centuries of the $2^{\text {nd }}$ mil. BC (on the base of the recently found lists of eponyms); they precede Old Hittite texts for ca. 250 years. At that time the two Anatolian groups of dialects - a Northern (Hittite) one, displaying centum dialect features, and a Southern (Luwian), partly similar to the satam languages - were already quite distinct.

From the very beginning, the idea of the Indo-European homeland in the Near East was connected to the discovery of a possible link between the appearance of speakers of Indo-European dialects in Europe and the spread of the new farming technology. This trend of thought has been developed in the archeological works of Sir Colin Renfrew. Subsequent attempts to support this hypothetical connection were made by comparing genetic data on the time and space characteristics of the European population. The farming terms common to Indo-European and other linguistic families discussed above show that the innovations were not restricted to one group of languages and were transmitted and exchanged between different ethnic formations. The area of the interference of these families coincides with the kernel of the rising farming in the Near East. That process of global (multilingual and multicultural) change had led to the diffusion of the results of the Neolithic revolution. The main directions of this diffusion coincide with the trends of the Indo-European migrations, but the new objects might have been introduced earlier than some of their Indo-European names and the latter might precede the coming of those who coined the terms.

The spread of Near Eastern innovations in Europe roughly coincides with the split of Proto-IndoEuropean (possibly in the early $5^{\text {th }}$ mil. BC), but some elements of the new technology and economy might have penetrated it much earlier (partly through the farmers close to the Tyrrhenian population as represented 5300 years ago by the genome of the Tyrolean Iceman). The diffusion took several thousand years and was probably already all over Europe ca. 3550 BC. At that time Indo-European migrations were only beginning. The speakers of the dialects of Proto-Indo-European living near the kernel of the technological revolution in Anatolia should have acquired the main results of this development. The growth of farming economy in Europe became more active with the split of the proto-language and the dispersal of the Indo-Europeans. The astonishing scope and speed of that process were afforded by the use of the domesticated horse and wheeled vehicles. The Indo-Europeans did not have to be pioneers in this field, but they were probably skillful in spreading other peoples' innovations. Recent work on the Botai culture of North Kazakhstan makes it possible to suppose a contribution of the ProtoYeniseian people to the development of horse domestication. For approximately fifteen hundred years serious preparatory work on horse domestication and the use of wheeled vehicles had been going on in different parts of Eurasia. Then, almost suddenly, the results are witnessed. On the border of the $3^{\text {rd }}$ and $2^{\text {nd }}$ mil. BC both of these important innovations appear together, usually in a context implying the presence of Indo-Europeans: traces of Near East-type chariots and the ritual use of the horse are clear in (probably Ancient Iranian) Margiana (Gonur), we see chariots on the Anatolian type of seals in Kanish; 
Hurrian sculptures and other symbols of horse abound in Urkeš as if foretelling the future Mespotamian-Aryan and Hurrian excellent training of horses in Mitanni (as later in Urartu). One of the first examples of the sacrificial horses used together with chariots in an archaic ritual was found in Sintashta; the following studies of the cities of the Transuralian Sintashta-Arkaim area made it clear that some Indo-European (and maybe Iranian as well) elements were at least partly present there.

The movement of Indo-Europeans to the north of the Caspian Sea in the northeast direction documented in the Sintashta-Arkaim complex led them much farther to the Altai-Sayany area where recent genetic investigations found traces of a Caucasoid element. Another Indo-European group moving in a parallel eastward direction using the South Silk Road caused the presence of a similar anthropological group among the population of Central Asia. It may be supposed that the Caucasoid anthropological type of the Iranian and/or Tocharian population of Eastern Turkestan, attested in the mummies recently found there as well as in the contemporary images of the native people, should be considered as the result of these migrations from the West to the East. The problem whether the boats played a role comparable to that of chariots at the time of early migrations is still to be decided by maritime archaeology. It seems that before the efficient use of chariots and horses, long-term mass movements were hardly possible. The first changes in the geographical position of separate dialects, e.g. when the Anatolians separated the Greeks from the rest of the East Indo-European group (that included the Armenians and IndoIranians), were caused by rather small-scale migrations close to the original homeland in the Near East.

Keywords: Indo-European languages, Semitic languages, Caucasian languages, Indo-European homeland, migrations, cattle-breeding, agriculture. 